Archive for

Organic Chemistry

Arkivoc 2018, part v, 0-0

\title{
An eco-compatible access to diversified bisoxazolone and bisimidazole derivatives
}

\author{
Wael Abdelgayed Ahmed Arafa*a,b and Ahmed Fawzy Abdel-Magied, ${ }^{c, d}$ \\ ${ }^{a}$ Chemistry Department, College of Science, Jouf University, P.O. Box 72341, Sakaka, Aljouf, \\ Kingdom of Saudi Arabia \\ ${ }^{b}$ Chemistry Department, Faculty of Science, Fayoum University, P.O. Box 63514, Fayoum City, Egypt \\ 'Chemistry Department, Royal Institute of Technology, KTH, SE-100 44, Stockholm, Sweden \\ ${ }^{d}$ Nuclear Material Authority, P.O. Box 530, El Maadi, Cairo, Egypt \\ Email: waa00@fayoum.edu.eg waarafa@ju.edu.sa
}

Received 02-21-2018

Accepted 04-28-2018

Published on line 05-27-2018

\section{Abstract}

An efficient, straight-forward and eco-friendly synthetic strategy for the assembly of novel bisoxazolones via a four-component, sequential reaction of dialdehydes, glycine, benzoyl chloride and acetic anhydride, using ultrasound radiation, is described. Additionally, a diverse group of new bisimidazoles has been synthesized in good yields by the sonication of diamines and ( $Z$ )-4-arylidene-2-phenyloxazol-5(4H)-ones. These approaches have resulted in a number of successful routes for the facile synthesis of bis-oxazolone and bis-imidazole frameworks within minutes of irradiation. Excellent outcomes using these environmentally-friendly parameters make these synthetic schemes ideal, sustainable, green-chemistry procedures and provide simple access towards the preparation of bisheterocycles.

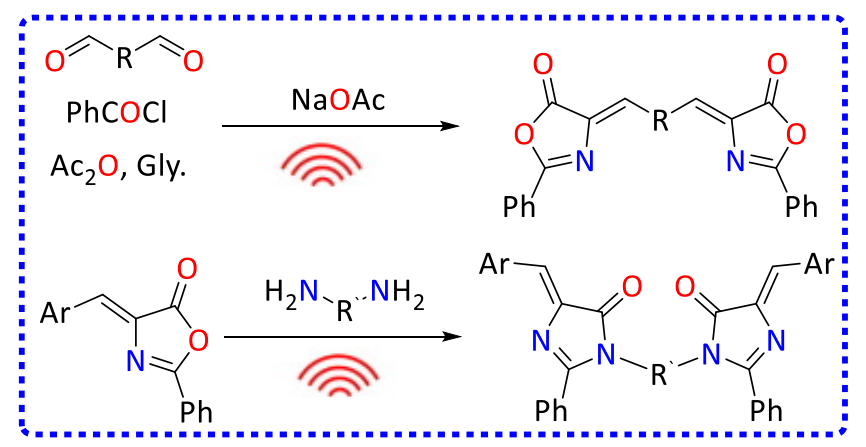

Keywords: Bisoxazolones, bis-imidazoles, solvent-free, ultrasound-assisted, multi-component synthesis 


\section{Introduction}

Arylidene azlactones (4-arylidene-2-phenyl-5(4H)oxazolones) have attracted much interest with respect to their broad range of chemotherapeutic activities. ${ }^{1-3}$ They are convenient, significant intermediates and building blocks for the assembly of a variety of biologically-active compounds comprising peptides ${ }^{4-7}$ and amino acids. ${ }^{8,9}$ Moreover, these compounds are valuable precursors for the design of photosensitive and biosensors devices for proteins. ${ }^{10}$ The best known strategy for the preparation of oxazolones is generally regarded to be the Erlenmeyer reaction, which involves the reaction of $\mathrm{N}$-benzoylglycine (hippuric acid) with aldehydes in the presence of a basic catalyst ( $\mathrm{NaOAc}$ ) and dehydrating agent $\left(\mathrm{Ac}_{2} \mathrm{O}\right) \cdot{ }^{11}$ After the Erlenmeyerreaction method, several other catalysts, dehydrating agents and methods have been utilized for condensation of hippuric acid (HA) and several carbonyl compounds. ${ }^{12-15}$ Nevertheless, several of these protocols have some disadvantages, including prolonged reaction times, poor yields, use of hazardous chemicals, and often harsh reaction conditions. ${ }^{16,17}$ Our group developed a new strategy for the assembly of arylideneoxazolones starting from arylidenemalononitriles using solvent-free conditions. ${ }^{18}$ Although several structural analogs have been prepared, a careful literature survey showed that only one synthetic method has been used for the construction of bisoxazolones. ${ }^{19}$ Hence, the development of more convenient and ecofriendly strategies for the preparation of oxazolones and bisoxazolones would be advantageous.

Imidazole is one of a number of remarkable $\mathrm{N}$-heterocyclic structures which are present in a variety of synthetic pharmaceuticals and natural products. ${ }^{20}$ Regardless of the number of reaction protocols that have been established for the synthesis of imidazole moieties, ${ }^{20-25}$ the development of a highly-efficient synthesis for the preparation of a series of novel bis-imidazoles from easily available substances in a one-step reaction, is one of the most intriguing challenges of modern synthetic chemistry. Recently, 'green-chemistry' syntheses, including the employment of ultrasonic- and microwave-irradiation techniques, have received special interest for achieving this goal. ${ }^{26-29}$ Ultrasonic irradiation, compared with other conventional techniques, has some inherent merits, e.g., milder reaction conditions, higher yields, shorter reaction times and simpler work-ups. As part of our efforts to prepare bis-heterocyclic systems using environmentally-benign conditions, ${ }^{30-34}$ we describe, herein, efficient protocols for the preparation of bis-oxazolones and bis-imidazoles driven by ultrasonic irradiation.

\section{Results and Discussion}

As a continuation of our work towards developing novel protocols for the synthesis of oxazolones ${ }^{18}$ and bisheterocycles from dialdehydes, ${ }^{30,34}$ we have progressed with respect to the design and preparation of the bisoxazolones (2a-f). In this context, reactive precursors such as dialdehyde derivatives (1a-f) can react effectively with hippuric acid $(\mathrm{HA})$ and acetic anhydride $\left(\mathrm{Ac}_{2} \mathrm{O}\right)$. We commenced our investigation using a model reaction of 2-hydroxy-5-methylisophthalaldehyde (1a) with $\mathrm{HA}$ and $\mathrm{Ac}_{2} \mathrm{O}$ in the presence of sodium acetate ( $\mathrm{NaOAc}$ ). Based on the results of our previous investigations, the reaction of $\mathrm{HA}$ with $\mathrm{Ac}_{2} \mathrm{O}$ should yield 2-phenyloxazol$5(4 H)$-one, which would subsequently interact with dialdehyde (1a) to afford the target bis-oxazolone product (2a) (Scheme 1). 
<smiles>Cc1cc(C=O)c(O)c(C=O)c1</smiles>

$1 \mathbf{a}$<smiles>O=C(O)COC(=O)CNC(=O)c1ccccc1</smiles>

Base

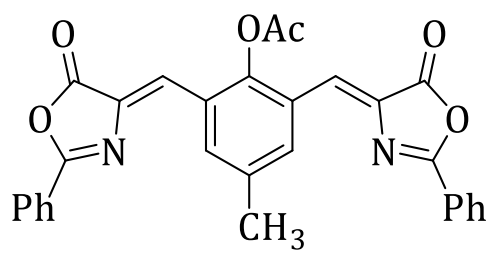

$2 a$

Scheme 1. Model reaction of 2-hydroxy-5-methylisophthalaldehyde (1a) with hippuric acid (HA) and acetic anhydride $\left(\mathrm{Ac}_{2} \mathrm{O}\right)$ in presence of sodium acetate ( $\left.\mathrm{NaOAc}\right)$.

The three-component reaction could be effected by blending all the substrates under ultrasonic irradiation $(40 \mathrm{kHz})$. The reaction was achieved at room temperature $\left(23^{\circ} \mathrm{C}\right)$ in a sealed vial for 10 minutes (Table 1, entry 1). Regrettably, the reaction afforded the desired product in poor yield (15\%) and the dialdehyde (1a) remained mostly unreacted. Slight improvements in yield were observed by increasing both temperature and time (Table 1, entries 2 and 3), however, multiple spots on the TLC plates indicated the presence of other compounds. These unsatisfactory outcomes prompted us to investigate the abovementioned three-component reaction in a sequential pattern of ultrasound radiation (US), ultrasound radiation plus heating (US/Conv.), and microwave radiation (MW).

We initially carried out the reaction between $\mathrm{HA}$ and $\mathrm{Ac}_{2} \mathrm{O}$ in the presence of $\mathrm{NaOAC}$ with sonication for 3 min at $40^{\circ} \mathrm{C}$. Interestingly, the formation of 2-phenyloxazol-5(4H)-one was completed within 2 min (confirmed by NMR analysis). The dialdehyde (1a) was then added and the resulting mixture was sonicated for an additional $3 \mathrm{~min}$ at $40^{\circ} \mathrm{C}$. After cooling, the, hitherto, unreported bisoxazolone derivative (2a) was obtained in $83 \%$ overall yield (Table 1, entry 4). Reaction analysis (by TLC) indicated the incomplete transformation of the intermediate 2-phenyloxazol-5(4H)-one into the final product (2a). Therefore, the reaction was repeated at elevated temperatures, viz. 50 and $60{ }^{\circ} \mathrm{C}$, which provided (2a) in $90 \%$ and $97 \%$ yields, respectively (Table 1, entries 5 and 6 ). It was also observed that a shorter irradiation period $(4 \mathrm{~min}$ ) diminished the yield slightly (Table 1, entry 7) while a longer period ( $8 \mathrm{~min}$ ) provided no advantage (Table 1, entry 8 ). Next, a series of other catalysts, including piperidine (Pip.), zinc oxide $(\mathrm{ZnO})$ and potassium phosphate $\left(\mathrm{K}_{3} \mathrm{PO}_{4}\right)$ were screened; of these, $\mathrm{NaOAc}$ was found to be the most efficient catalyst for this conversion (see Table 1 , entry 8 vs. entries 9-11). In order to compare the effectiveness and applicability of ultrasonic irradiation on the template reaction, a control experiment was performed, utilizing thermal heating $\left(100{ }^{\circ} \mathrm{C}\right)$ with the NaOAc catalyst (Table 1, entry 12). A good yield was acquired (67\%), however, with longer time (2h). These results demonstrated that ultrasonic irradiation can make the current one-pot method occur efficiently and rapidly, while heating decreases the rate and yield of the reaction. Carrying out the model reaction under microwave irradiation produced the desired product (2a) in poor yield (Table 1, entry $13,45 \%$ ) and generation of a Perkincondensation product (4, Scheme 3 ).

As shown in Table 1, it was found that the ultrasonic-assisted method is more effective (Table 1 , entry 6 ) than both the conventional heating (Table 1, entry 12) and microwave (Table 1, entry 13) conditions with respect to time and yield. After $2 \mathrm{~min}$ of sonication, a yellow color (oxazolone) was observed this, in turn, crystallized out as a yellow mass following addition of dialdehyde (1a). This solid was then filtered off to afford the pure bis-oxazolone (2a). 
Table 1. Optimization of reaction conditions for the preparation of bis-oxazolone derivative (2a)

\begin{tabular}{|c|c|c|c|c|c|}
\hline Entry & Catalyst & Conditions & Temperature $\left({ }^{\circ} \mathrm{C}\right)$ & Time (min) & Yield (\%) \\
\hline 1 & $\mathrm{NaOAC}$ & $U^{a}$ & $23(r t)$ & 10 & 15 \\
\hline 2 & $\mathrm{NaOAc}$ & $U^{a}$ & 40 & 15 & 23 \\
\hline 3 & $\mathrm{NaOAc}$ & $U^{a}$ & 40 & 20 & 28 \\
\hline 4 & $\mathrm{NaOAC}$ & $U^{b}$ & 40 & 6 & 83 \\
\hline 5 & $\mathrm{NaOAc}$ & $U^{b}$ & 50 & 6 & 90 \\
\hline 6 & $\mathrm{NaOAc}$ & $U^{b}$ & 60 & 5 & 97 \\
\hline 7 & $\mathrm{NaOAC}$ & $U^{b}$ & 60 & 4 & 92 \\
\hline 8 & $\mathrm{NaOAC}$ & $U^{b}$ & 60 & 8 & 97 \\
\hline 9 & Pip. & $U^{b}$ & 60 & 6 & 84 \\
\hline 10 & $\mathrm{ZnO}$ & $U^{b}$ & 60 & 6 & 73 \\
\hline 11 & $\mathrm{~K}_{3} \mathrm{PO}_{4}$ & $U^{b}$ & 60 & 6 & 80 \\
\hline 12 & $\mathrm{NaOAC}$ & Conv. $^{b}$ & 100 & 120 & 67 \\
\hline 13 & $\mathrm{NaOAC}$ & $\mathrm{MW}^{\mathrm{b}}$ & 120 & 60 & 45 \\
\hline
\end{tabular}

a The mixture of $1 \mathrm{a}(0.05 \mathrm{mmol}), \mathrm{HA}(1 \mathrm{mmol})$ and $\mathrm{Ac}_{2} \mathrm{O}(1 \mathrm{~mL})$ was sonicated in the presence of $\mathrm{NaOAc}(1.1 \mathrm{mmol})$. ${ }^{\mathrm{b}}$ The mixture of $\mathrm{HA}(1 \mathrm{mmol})$, base $(1.1 \mathrm{mmol})$ and $\mathrm{Ac}_{2} \mathrm{O}(1 \mathrm{~mL})$ was heated using US, US/Conv., Conv. or MW for the indicated times, then $0.05 \mathrm{mmol}$ of $1 \mathrm{a}$ was added and heating was continued for the indicated times. US = ultrasound; Conv. = conventional heating; $\mathrm{MW}=$ microwave; Pip. = piperidine

To investigate the generality and scope of this protocol, several dialdehydes bearing an electron-donating group (1a) and electron-withdrawing groups (1b and $\mathbf{1 c}$ ) were reacted with $\mathrm{HA}$ and $\mathrm{Ac}_{2} \mathrm{O}$, in the presence of $\mathrm{NaOAc}$, under ultrasonic-assisted conditions (Scheme 2, method A). Interestingly, the respective products (2ac) were acquired in significant yields in both cases. Furthermore, the methodology was successfully extended to other dialdehydes, for instance, terephthalaldehyde (1d) in $97 \%$ yield (literature-reported yield $78 \%)^{19}$, heterocyclic dialdehydes such as $1 \mathrm{H}$-pyrazole-3,5-dicarbaldehyde (1e) (89\% yield), and 4-(3-formyl-4hydroxybenzyl)-2-hydroxybenzaldehyde (1f) (94\% yield).

Four-component reactions of dialdehydes (1a-f), glycine, benzoyl chloride, and $\mathrm{Ac}_{2} \mathrm{O}$ have also been studied, providing direct access to bis-oxazolones (Scheme 2, method B). Benzoyl chloride, glycine, $\mathrm{Ac}_{2} \mathrm{O}$ and fused $\mathrm{NaOAC}$ were sonicated at $60{ }^{\circ} \mathrm{C}$ for $3 \mathrm{~min}$ to furnish 2-phenyloxazol-5(4H)-one. Following that, dialdehydes (1a-f) were added and sonication was recommenced for another $3 \mathrm{~min}$ at the same temperature. The bis-oxazolones (2a-f) were obtained in excellent yields and high purity. Notably, this newly developed four-component reaction under sonication gave nearly similar yields compared with method $A$.

On mixing the model substrates (1a), $\mathrm{HA}, \mathrm{Ac}_{2} \mathrm{O}$ and $\mathrm{NaOAc}$ together under increased thermal conditions of $120^{\circ} \mathrm{C}$, multiple spots were observed in addition to the anticipated product (2a) on TLC. Using preparative TLC methodology, the mixture was resolved and three derivatives were isolated and identified as $\left(4 Z, 4^{\prime} Z\right)-4,4^{\prime}-((2-$ hydroxy-5-methyl-1,3-phenylene)bis(methanylylidene))bis(2-phenyloxazol-5(4H)-one) (2a, 34\%), and the unexpected products (Z)-4-[(6-methyl-2-oxo-2H-chromen-8-yl)methylene]-2-phenyloxazol-5(4H)-one (3, 60\%) and a small amount of the 3,3'-(2-acetoxy-5-methyl-1,3-phenylene)diacrylic acid (4, 6\%) (Scheme 3). Proposed mechanistic routes to (2a), (3) and (4) are shown in Scheme 4. 


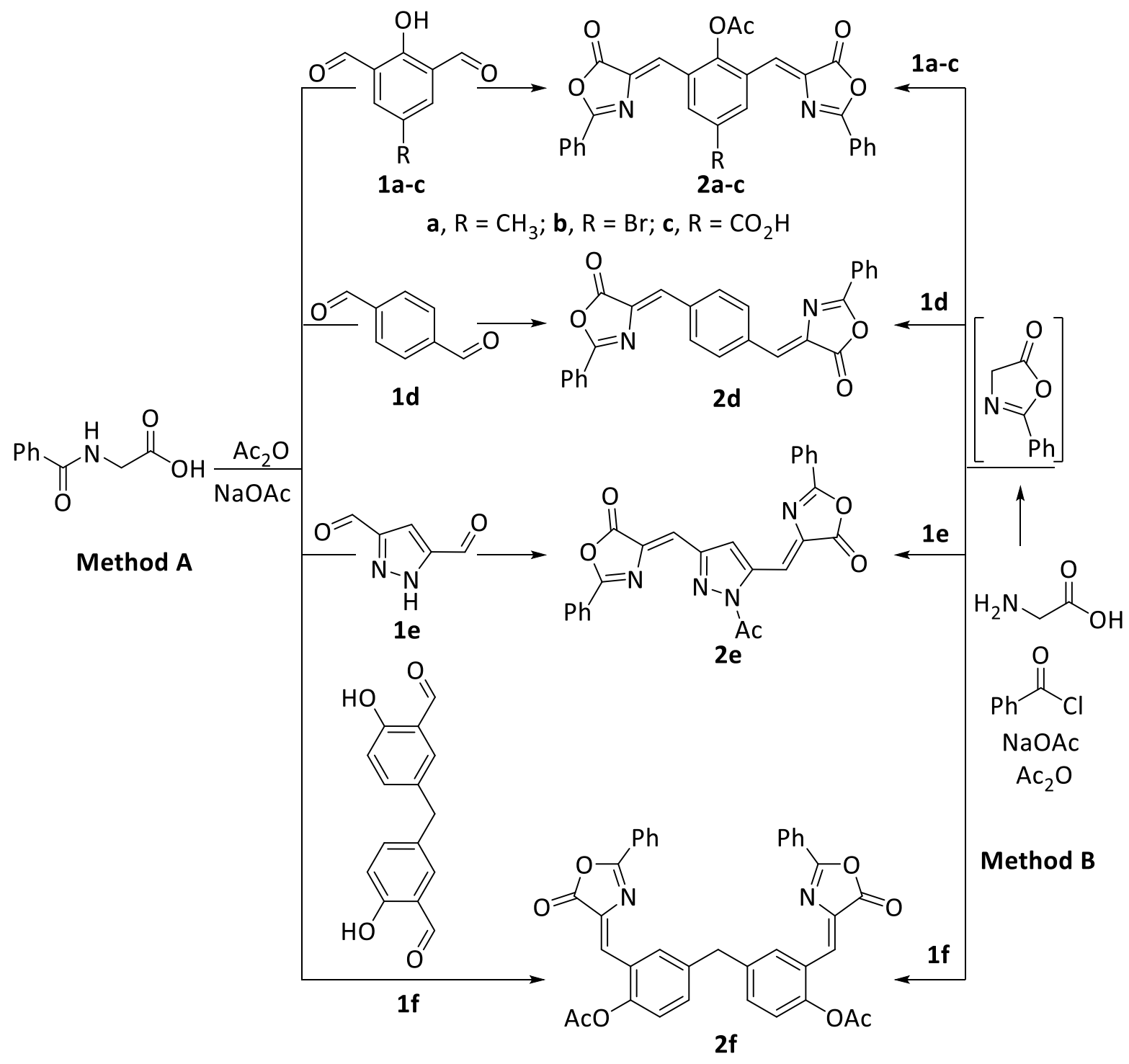

Scheme 2. Proposed synthetic routes to bis-oxazolones (2a-f) using methods A and B.

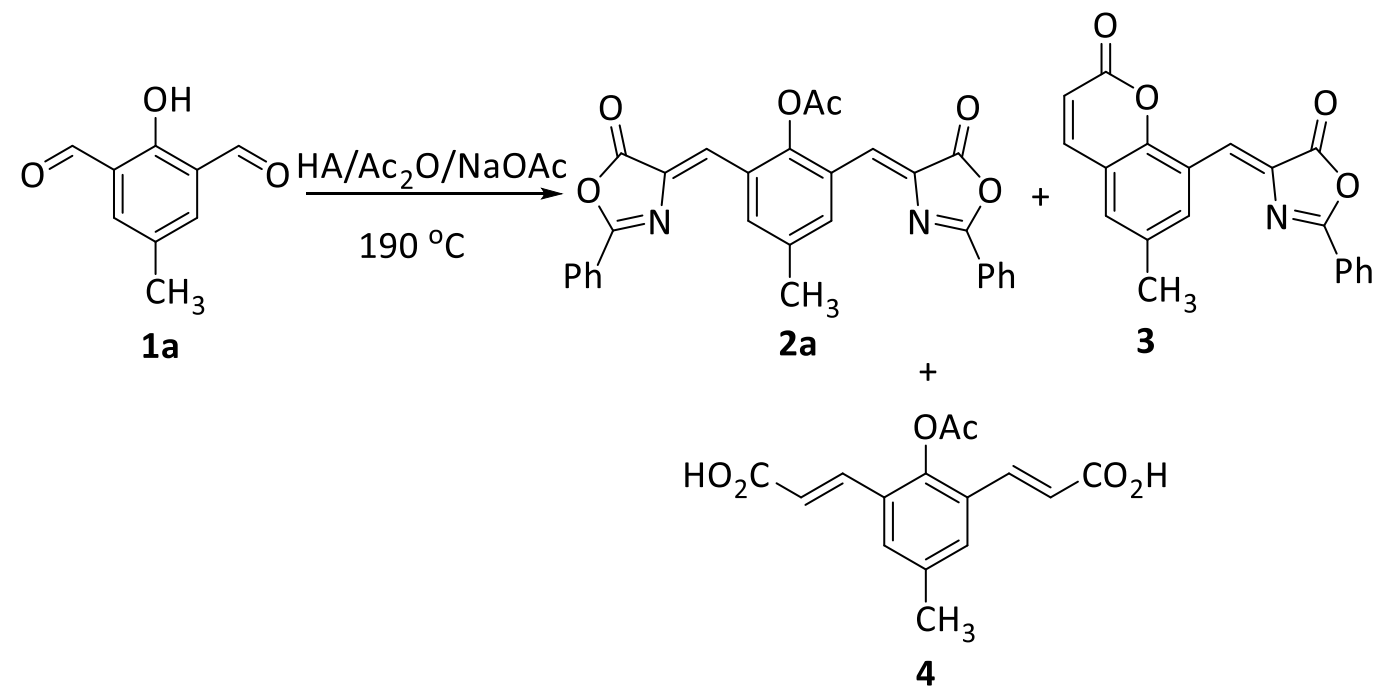

Scheme 3. Formation of (2a) and derivatives (3) and (4) at elevated temperature. 
The proposed structures of the prepared bisoxazolones (2a-f) were confirmed based on the spectral analyses (mass spectra, IR and NMR spectroscopies). The IR spectra of (2a-f) exhibited sharp bands around $v$ $1790 \mathrm{~cm}^{-1}$ assigned to $\mathrm{C}=\mathrm{O}$. The constructed heterocyclic system was confirmed by the absence of any bands attributed to amidic $\mathrm{NH}$ or carboxylic $\mathrm{OH}$ functional groups. Despite the fact that there are two possible geometric isomers for derivatives $(\mathbf{2 a}-\mathbf{f})$, we presumed that the configuration around the $\mathrm{C}=\mathrm{C}$ double bond would be the thermodynamically more favourable Z-isomer, by analogy of the synthetic procedure utilized here with previously reported preparations of Z-oxazolones. ${ }^{35}$ In the ${ }^{1} \mathrm{H}$ NMR spectra of (2a-f), only one set of signals exists in each spectrum, demonstrating that only one of the geometric isomers, the thermodynamically-preferred Z-isomer, was formed. Furthermore, the signal patterns denote that the two oxazolone moieties are chemically equivalent, meaning that the oxazolone molecules are symmetric with respect to the central ring.

As presented in Scheme 4, a reasonable mechanism of this reaction at $190{ }^{\circ} \mathrm{C}$ would be an intramolecular aldol-type condensation of the initially formed O-acetyl derivative (5) to generate the non-isolable coumarin intermediate (6). This intermediate could then undergo a condensation reaction with the formed oxazolone anion (7), yielding the isolable derivative (3). Perkin-condensation compound (4) was also formed in this step. The formation of bisoxazolone (2a) may be due to the carbanion (7) attacking both carbonyl groups of the dialdehyde (1a).

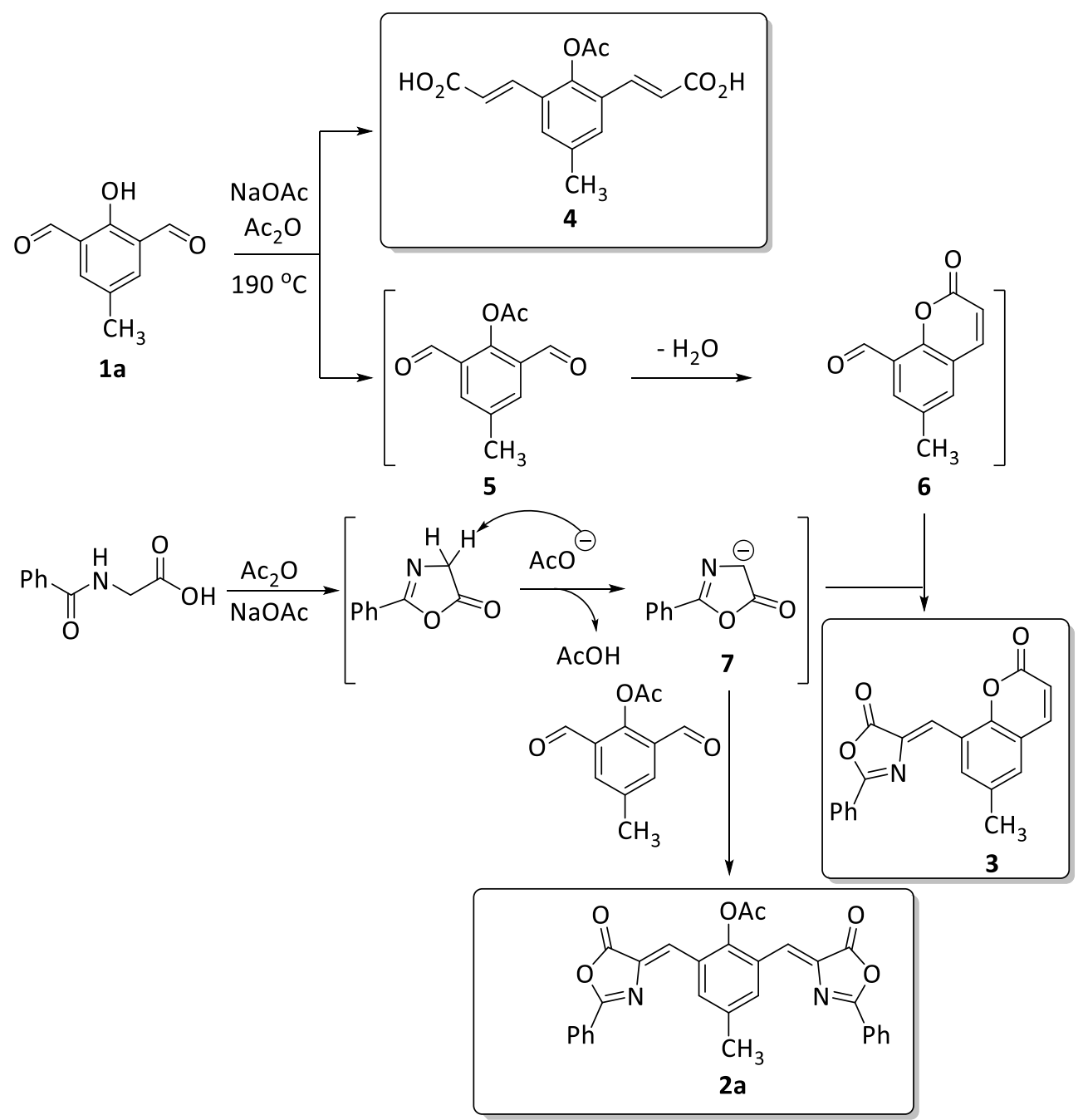

Scheme 4. Proposed mechanisms for the syntheses of derivatives (2a), (3) and (4). 
To further expand the scope of the substrates, several aromatic carbonyl compounds (8a-f) were also investigated under these sequential protocols (Scheme 5 , methods $A$ and $B$ ). The reactions afforded the corresponding oxazolones (9a-f) in excellent yields.

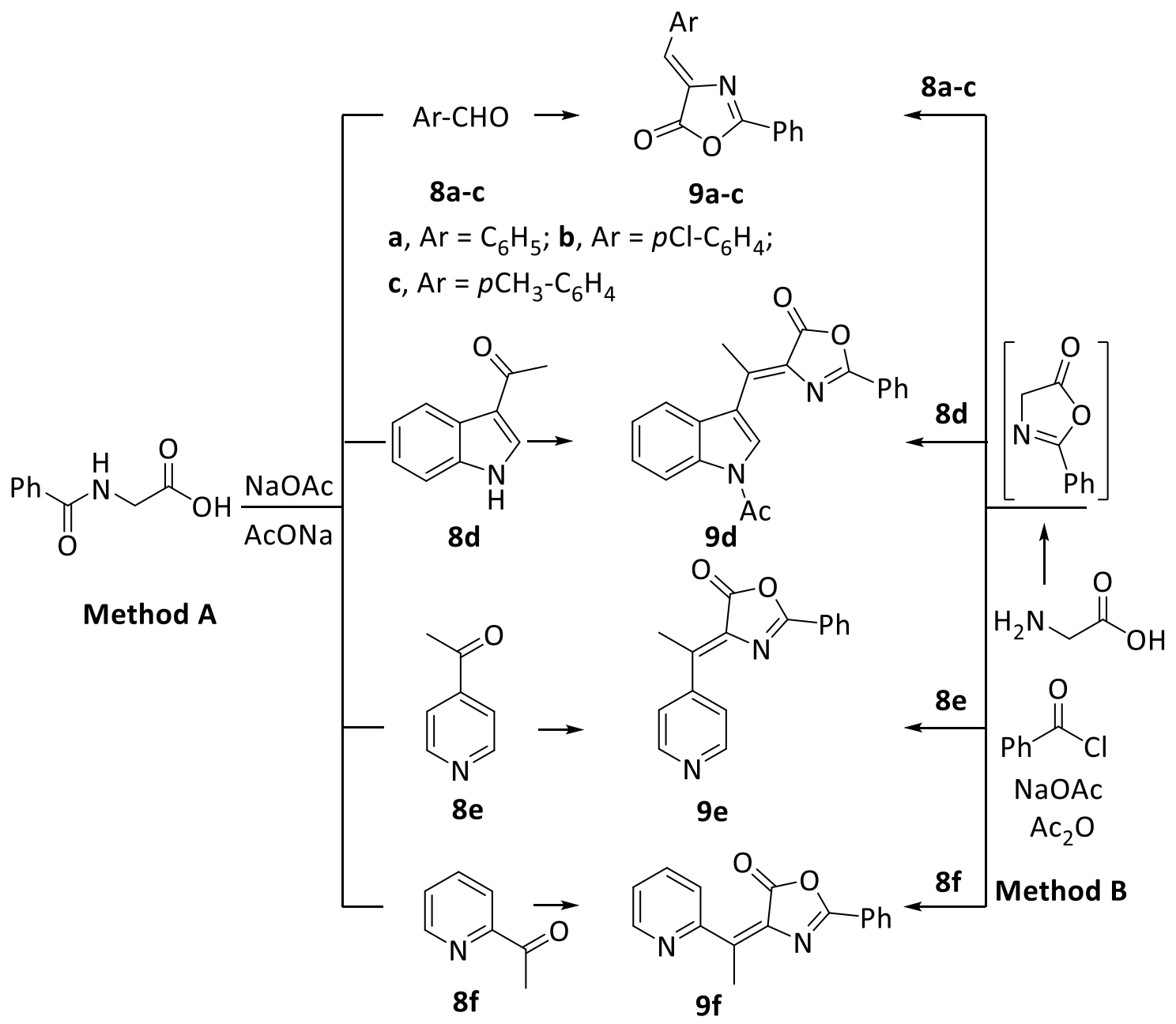

Scheme 5. Syntheses of oxazolones (9a-f) using methods A and B.

From a green-chemistry perspective, it would be valuable to compare our new methods with a conventional solvent/heating method (C) for the construction of bis-oxazolones using several 'green' metrics; ${ }^{36}$ for example, Process Mass Intensity (PMI), E-factor, Reaction Mass Efficiency (RME) and Yield Economy (YE), which would then enable us to assess the strength of our chemical procedures. To accomplish this, the reaction should be scalable to gram level. Therefore, we performed gram-scale preparations of derivative (2a) utilizing methods A, B and C (Scheme 6). Using Method A, reacting dialdehyde (1a) (5 mmol) with HA (10 mmol) under sonication at $60{ }^{\circ} \mathrm{C}$ for 5 min provided $2.41 \mathrm{~g}$ of (2a) (98\% yield) (Table 2, entry 1). Using Method B, reacting dialdehyde (1a) $(5 \mathrm{mmol})$ with glycine $(10 \mathrm{mmol})$ and benzoyl chloride $(10 \mathrm{mmol})$ under sonication at $60^{\circ} \mathrm{C}$ for 6 min gave $2.36 \mathrm{~g}$ of (2a) (96\% yield) (Table 2, entry 2). Using Method C, reacting dialdehyde (1a) $(5 \mathrm{mmol})$ with $\mathrm{HA}(10 \mathrm{mmol})$ in a water bath $\left(100{ }^{\circ} \mathrm{C}\right)$ for $2 \mathrm{~h}$ afforded $1.70 \mathrm{~g}$ of $(2 \mathrm{a})(69 \%$ yield $)$ (Table 2, entry 3). 


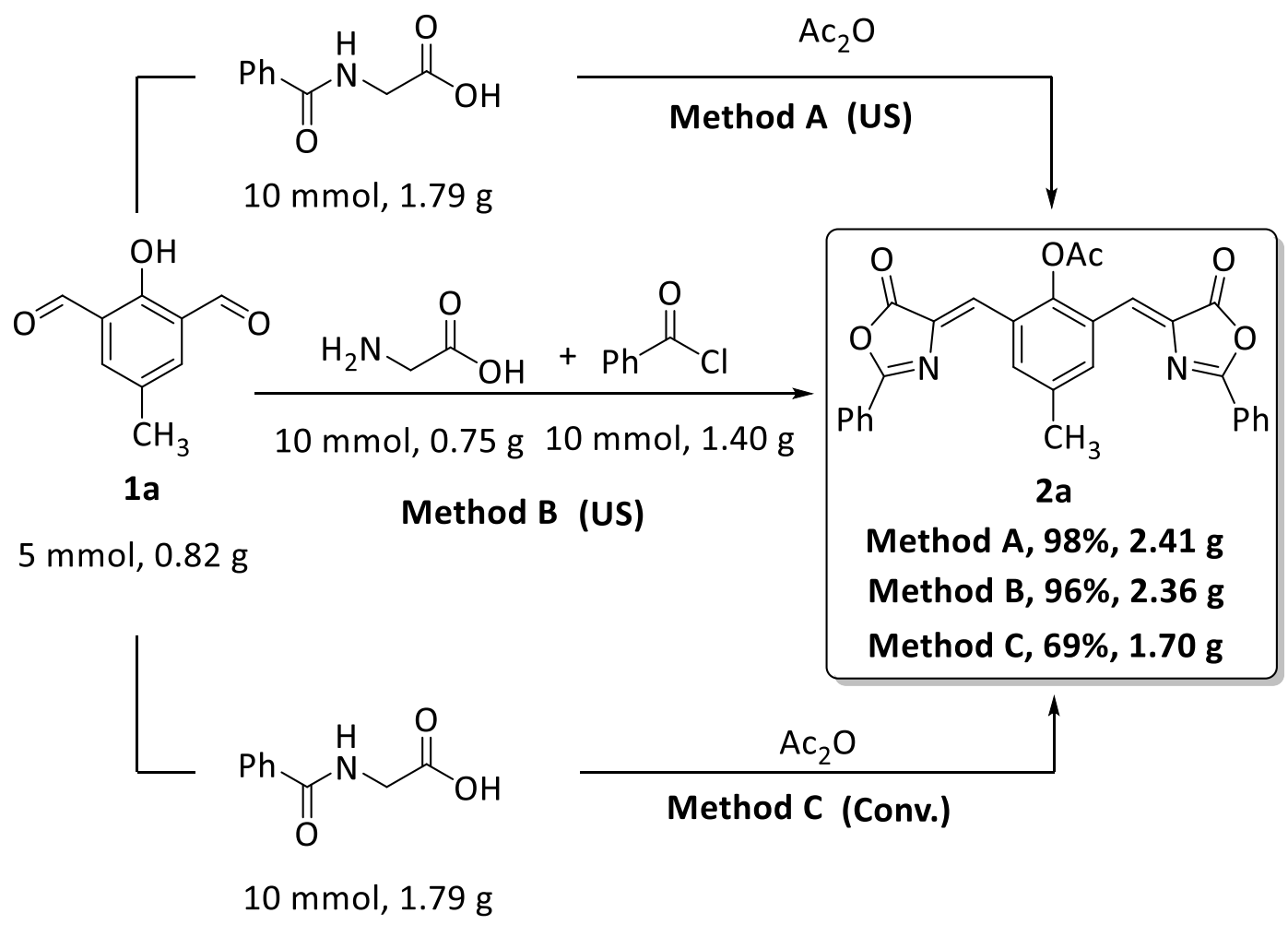

Scheme 6. Scaled-up synthesis of bis-oxazolone (2a) using ultrasonic and conventional methods.

Table 2. Comparison of reaction efficiencies and sustainability metrics of ultrasonic methods $(A, B)$ and conventional method $(C)$ for preparation of bis-oxazolone derivative (2a)

\begin{tabular}{ccccccc}
\hline Entry & Method & Yield (\%) & E-factor & PMI & RME (\%) & YE (\%) \\
\hline 1 & A & 98 & 0.020 & 1.13 & 88.86 & 19.60 \\
2 & B & 96 & 0.041 & 1.30 & 76.82 & 16.00 \\
3 & C & 69 & 0.309 & 1.81 & 55.34 & 0.575 \\
\hline
\end{tabular}

The higher values of sustainability metrics YE (19 and 16) and RME ( 88.8 and 76.8), and smaller values of E-factor (0.020 and 0.041) and PMI (1.13 and 1.30), make the investigated ultrasound-assisted protocols $A$ and $B$ ideal sustainable green processes for construction of mono- and bisoxazolones vs. the reported moreconventional process (C) when comparable reaction chemistries are applied.

In the course of our investigations for developing novel protocols to construct bis-heterocycles, we have also established an efficient and simple methodology for the preparation of bisimidazoles. Bis-imidazoles (11a-i) were synthesized simply by reacting diamines (10a-c) with (Z)-4-arylidene-2-phenyloxazol-5(4H)-ones $(9 \mathrm{a}-\mathrm{c})$, in the presence of catalytic amounts of $\mathrm{NaOAc}$, using sonication for $10 \mathrm{~min}$ at $80{ }^{\circ} \mathrm{C}$ (Scheme 7). 


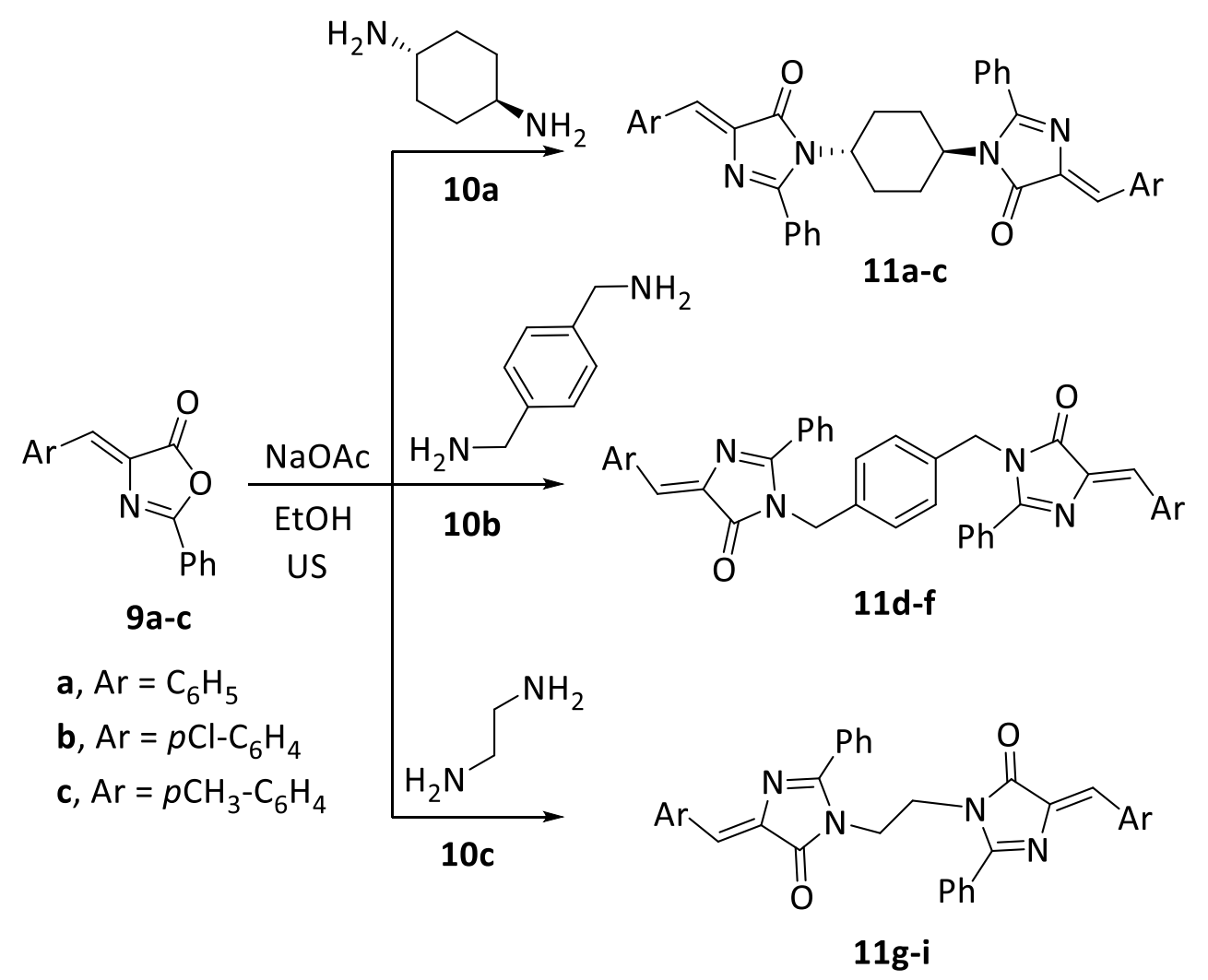

Scheme 7. Synthetic routes to bisimidazoles (11a-i).

It is worth mentioning that microwave irradiation also gave the desired bisimidazoles (11a-i) in almost the same yields, but following longer reaction times ( $40 \mathrm{~min}, 120^{\circ} \mathrm{C}$ ). The reaction seems to be tolerant to several substitutions on the oxazolone cores as well as the diamines. A slightly lower yield was obtained, however, in the case of 1,4-phenylenedimethanamine (10b) vs. both the 1,4-trans-cyclohexane-1,4-diamine (10a) and ethylenediamine (10c). Oxazolones substituted with methyl- and chloro- functional groups furnished the expected bisimidazoles (11b), (11c), (11e), (11f), (11h) and (11i) in better yields (94-97\%). Also, compound (9a) afforded the best yield with 1,4-trans-cyclohexane-1,4-diamine (10a) (95\%).

The structures of products (11a-i) were fully characterized by NMR, IR, and MS. The IR spectrum of derivative (11a) displayed characteristic bands at 1697 and $1635 \mathrm{~cm}^{-1}$ which were attributed to oxo-imidazole carbonyl $(C=O)$ and azomethine $(C=N)$ stretching frequencies, respectively. The ${ }^{1} \mathrm{H} N M R$ spectrum of (11a) exhibited one down-field singlet at $7.27 \mathrm{ppm}$ which was assigned to the methine-group proton $(\mathrm{C}=\mathrm{CH})$; this confirmed the isolation of the thermodynamically more favourable Z-isomer preferentially over the $E$-isomer. The protons of the phenyl rings displayed three multiplets in the range of $8.21-7.29 \mathrm{ppm}$. Additionally, for derivative (11a), the protons of the cyclohexane ring were observed as multiplets in the 4.24-1.72 ppm range. Also, the ${ }^{13} \mathrm{C}$ NMR of derivative (11a) agreed with the number of carbons. These results were supported further by the mass spectrum which exhibited the molecular-ion peak at $m / z 604.28\left(\mathrm{M}^{+}, 1.6 \%\right)$, in agreement with the molar mass of the proposed structure. To assess our protocol on the "greenness" scale once again, we performed a gram-scale preparation of bis-imidazole (11g) (Table 3) by condensing oxazolone (9a) (10 $\mathrm{mmol}, 2.49 \mathrm{~g}$ ) with ethylene diamine ( $5 \mathrm{mmol}, 0.3 \mathrm{~g}$ ) using either ultrasonic irradiation for $10 \mathrm{~min}$ at $80{ }^{\circ} \mathrm{C}$ or in refluxing ethanol for $10 \mathrm{~min} .{ }^{37}$ (Scheme 8). Some green metrics were calculated for these reactions and the results are presented in Table 3 . The sonication method achieved good scores in comparison with the 
conventional method, thus establishing the sonication methodology to be an ideal green, environmentallysustainable method.

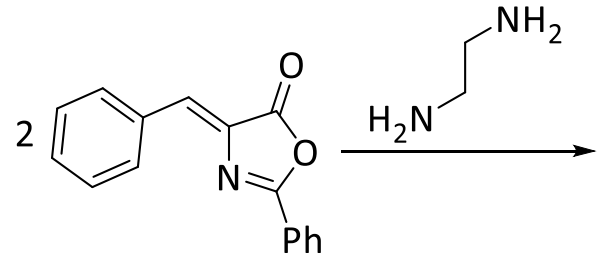

9a, $10 \mathrm{mmol}$ $2.49 \mathrm{~g}$
$5 \mathrm{mmol}$

$0.3 \mathrm{~g}$<smiles>O=C1/C(=C/c2ccccc2)N=C(c2ccccc2)N1CCN1C(=O)/C(=C/c2ccccc2)N=C1c1ccccc1</smiles>

11g, $2.45 \mathrm{~g}, 94 \%$ (US) $1.90 \mathrm{~g}, 73 \%$ (Conv.)

Scheme 8. Scale-up synthesis with yields of bisimidazole (11g) by ultrasonic (US) vs. conventional (Conv.) methods.

Table 3. A comparison of reaction efficiencies of different methods for the preparation of derivative (11g)

\begin{tabular}{cccccccc}
\hline Entry & Method & Time (min) & Yield (\%) & E-factor & PMI & RME (\%) & YE (\%) \\
\hline 1 & US $^{\mathrm{a}}$ & 10 & 94 & 0.058 & 1.14 & 87.81 & 9.4 \\
2 & Conv. $^{\mathrm{b}}$ & 10 & 73 & 0.27 & 1.47 & 68.10 & 7.3 \\
\hline
\end{tabular}

${ }^{a}$ Ultrasonic irradiation. ${ }^{b}$ Conventional method. ${ }^{37}$

\section{Conclusions}

A rapid, scalable and multi-component protocol for the assembly of a novel series of mono- and bis-oxazolone scaffolds through sequential reactions was demonstrated using ultrasonic irradiation. (Z)-4-Arylidene-2phenyloxazol-5(4H)-ones underwent ring transformation on sonication with several diamines to afford a new series of bisimidazoles. Key merits of these eco-friendly protocols over conventional methods include excellent functional-group tolerance, high yields, scalability, short reaction times, and easy work-up. These protocols display distinct advantages in terms of green-chemistry/sustainability metrics that can be of potential use for therapeutic-chemistry purposes and parallel synthesis applications.

\section{Experimental Section}

General. All chemicals and solvents were received commercially from Merck and Sigma-Aldrich chemical companies. Derivatives (1a-c, 1e) and (1f) were prepared following our reported methods. ${ }^{30,33}$ All known organic products $(\mathbf{2} \mathbf{d}),^{35}(\mathbf{9 a}-\mathbf{c}),{ }^{38,39}$ and $(\mathbf{1 1} \mathbf{g})^{37}$ were confirmed by comparison of their physical and spectral data with those of authentic samples. All of the melting points of the prepared compounds were determined on an Electrothermal IA9100 apparatus (UK). IR spectra of the samples were run using $\mathrm{KBr}$ disks on a PerkinElmer Spectrum One spectrometer. The NMR spectra were measured on a Bruker Avance $400 \mathrm{MHz}$ spectrometer using $\mathrm{CDCl}_{3}$ or DMSO- $d_{6}$. Ultrasonication was performed in a SY5200DH-T ultrasound cleaner (40 $\mathrm{kHz}$ ). Microwave irradiation was carried out using Biotage ${ }^{\circledR}$ Initiator Classic (Biotage AB; Uppsala, Sweden) using sealed vessels. 


\section{General procedures for the preparation of mono- and bis-oxazolones ( $2 a-f$ and $9 a-f)$}

Method A. A mixture of hippuric acid (HA) $(1.0 \mathrm{mmol})$, and freshly fused NaOAc $(1.1 \mathrm{mmol})$ was mixed in the presence of $\mathrm{Ac}_{2} \mathrm{O}(1 \mathrm{~mL})$ and the mixture was sonicated for $3 \mathrm{~min}$ at $60{ }^{\circ} \mathrm{C}$. Then, $0.5 \mathrm{mmol}$ of dialdehydes (1af) or $1.0 \mathrm{mmol}$ of carbonyl compounds $(\mathbf{8 a}-\mathbf{f})$ were added and the sonication was resumed for 2 min at the same temperature. Upon completion of the reaction (monitored by TLC), the mixture formed a yellow solid, which was washed with water $(2 \times 10 \mathrm{~mL})$, chilled in EtOH $(2 \times 10 \mathrm{~mL})$, and recrystallized from EtOH containing a few drops of dioxane to obtain the desired mono- and bisoxazolones (2a-f and $\mathbf{9 a}-\mathbf{f}$ ).

Method B. A mixture of glycine $(1.0 \mathrm{mmol})$, benzoyl chloride $(1.0 \mathrm{mmol})$ and freshly fused $\mathrm{NaOAc}(2.1 \mathrm{mmol})$ was mixed in the presence of $\mathrm{Ac}_{2} \mathrm{O}(1 \mathrm{~mL})$ and the mixture was sonicated for 3 minutes at $60{ }^{\circ} \mathrm{C}$. Then 0.5 mmol of dialdehydes (1a-f) or $1.0 \mathrm{mmol}$ of carbonyl compounds (8a-f) were added and the sonication was resumed for another $3 \mathrm{~min}$. Upon completion of the reaction (monitored by TLC), yellow solids separated out which were washed with water $(2 \times 10 \mathrm{~mL})$, chilled in $\mathrm{EtOH}(2 \times 10 \mathrm{~mL})$, and recrystallized from EtOH containing a few drops of dioxane to obtain the desired mono- and bis-oxazolones ( $2 a-f$ and $9 a-f)$.

4-Methyl-2,6-bis[(Z)-(5-oxo-2-phenyloxazol-4(5H)-ylidene)methyl]phenol acetate (2a). Yellow solid, (477 mg, 97\%). $\mathrm{mp} 211-213{ }^{\circ} \mathrm{C}$. IR (solid, KBr, $\left.\mathrm{v}_{\max }, \mathrm{cm}^{-1}\right)$ : 1793, 1738 (C=O), 1651 (C=N), 1591 (C=C). ${ }^{1} \mathrm{H} \mathrm{NMR} \mathrm{(400} \mathrm{MHz,}$ DMSO): $\delta_{\mathrm{H}} 8.11(4 \mathrm{H}, \mathrm{d}, J 7.5 \mathrm{~Hz}, 4 \mathrm{CH}$ aromatic), $7.84(2 \mathrm{H}, \mathrm{s},=\mathrm{CH}), 7.47(2 \mathrm{H}, \mathrm{s}, 2 \mathrm{CH}$ aromatic), 7.42-7.34 (6H, m, $6 \mathrm{CH}$ aromatic), $2.41\left(3 \mathrm{H}, \mathrm{s}, \mathrm{C}_{3}\right), 2.38\left(3 \mathrm{H}, \mathrm{s}, \mathrm{CH}_{3}\right) .{ }^{13} \mathrm{C} \mathrm{NMR}(100 \mathrm{MHz}, \mathrm{DMSO}): \delta_{\mathrm{C}} 169.5$ (CO), 167.2 (CO), 162.1, 148.1, 135.3, 131.7, 131.0, 129.8, 128.9, 128.8, 126.8, 121.5, 117.9 (C aromatic), $21.0\left(\underline{\mathrm{C}}_{3}\right), 20.7\left(\underline{\mathrm{CH}}_{3}\right)$. MS (ESI) $m / z$ (\%): $492.13\left(\mathrm{M}^{+}, 0.8\right), 105$ (100). Anal. calcd. for $\mathrm{C}_{29} \mathrm{H}_{20} \mathrm{~N}_{2} \mathrm{O}_{6}: \mathrm{C}, 70.73 ; \mathrm{H}, 4.09 ; \mathrm{N}$, 5.69. Found: C, $70.67 ; \mathrm{H}, 4.14 ; \mathrm{N}, 5.75$.

4-Bromo-2,6-bis[(Z)-(5-oxo-2-phenyloxazol-4(5H)-ylidene)methyl]phenol acetate (2b). Yellow solid, (545 mg, 98\%). mp 242-244 ${ }^{\circ} \mathrm{C}$. IR (solid, KBr, $v_{\max } \mathrm{cm}^{-1}$ ): 1803, 1737 (C=O), 1652 (C=N), 1598 (C=C). ${ }^{1} \mathrm{H} \mathrm{NMR}(400 \mathrm{MHz}$, DMSO): $\delta_{\mathrm{H}} 8.10(4 \mathrm{H}, \mathrm{d}, J 7.5 \mathrm{~Hz}, 4 \mathrm{CH}$ aromatic), $7.84(2 \mathrm{H}, \mathrm{s},=\mathrm{C} \underline{\mathrm{H}}), 7.74(2 \mathrm{H}, \mathrm{s}, 2 \mathrm{CH}$ aromatic), 7.51-7.48 (6H, m, $6 \mathrm{CH}$ aromatic), $2.37\left(3 \mathrm{H}, \mathrm{s}, \mathrm{CH}_{3}\right) ;{ }^{13} \mathrm{C} \mathrm{NMR}(100 \mathrm{MHz}, \mathrm{DMSO}): \delta_{\mathrm{C}} 169.1$ (C=O), 167.5 (C=O), 161.8, 149.7, 132.3, 131.6, 131.1, 128.7, 128.5, 123.8, 118.8, 118.4, (C aromatic), 20.9 ( $\left.\underline{C H}_{3}\right) . M S(E S I) ~ m / z ~(\%): 556.02\left(\mathrm{M}^{+}, 1.3\right)$, 105 (100). Anal. calcd. for $\mathrm{C}_{28} \mathrm{H}_{17} \mathrm{BrN}_{2} \mathrm{O}_{6}: \mathrm{C}, 60.34 ; \mathrm{H}, 3.07 ; \mathrm{N}, 5.03$. Found: $\mathrm{C}, 60.41 ; \mathrm{H}, 2.98 ; \mathrm{N}, 5.11$.

4-Acetoxy-3,5-bis[(Z)-(5-oxo-2-phenyloxazol-4(5H)-ylidene)methyl]benzoic acid (2c).

Yellow solid, (490 mg, 94\%). mp 234-235 ${ }^{\circ} \mathrm{C}$. IR (solid, $\mathrm{KBr}, v_{\max } \mathrm{cm}^{-1}$ ): 3324-3155 (OH), 1799, 1737, 1685 $(\mathrm{C}=\mathrm{O}), 1646(\mathrm{C}=\mathrm{N}), 1601(\mathrm{C}=\mathrm{C}) .{ }^{1} \mathrm{H}$ NMR $(400 \mathrm{MHz}, \mathrm{DMSO}): \delta_{\mathrm{H}} 11.70(1 \mathrm{H}, \mathrm{s}, \mathrm{OH}), 7.73(2 \mathrm{H}, \mathrm{s}, 2 \mathrm{CH}$ aromatic), 7.97-7.94 (4H, m, 4CH aromatic), $7.79(2 \mathrm{H}, \mathrm{s},=\mathrm{CH}), 7.53-7.48\left(6 \mathrm{H}, \mathrm{m}, 6 \mathrm{CH}\right.$ aromatic), $2.39\left(3 \mathrm{H}, \mathrm{s}, \mathrm{CH}_{3}\right) .{ }^{13} \mathrm{C}$ NMR (100 MHz, DMSO): $\delta_{C} 169.3$ (CO), 167.6 (CO), 167.3 (CO), 162.3, 149.9, 132.5, 131.9, 131.5, 129.3, 128.7, 126.5, 123.7, 118.7 (C aromatic), $21.2\left(\underline{C}_{3}\right)$. MS (ESI) $m / z(\%): 522.10\left(\mathrm{M}^{+}, 0.6\right), 105$ (100). Anal. calcd. for $\mathrm{C}_{29} \mathrm{H}_{18} \mathrm{~N}_{2} \mathrm{O}_{8}: \mathrm{C}, 66.67 ; \mathrm{H}, 3.47 ; \mathrm{N}, 5.36$. Found: $\mathrm{C}, 66.62 ; \mathrm{H}, 3.52 ; \mathrm{N}, 5.30$.

\section{(4Z,4'Z)-4,4'-[1,4-Phenylenebis(methanylylidene)]bis(2-phenyloxazol-5(4H)-one) (2d). ${ }^{35}$}

Yellow solid, (407 mg, 97\%). mp 281-283 ${ }^{\circ} \mathrm{C}$. IR (solid, $\left.\mathrm{KBr}, v_{\max }, \mathrm{cm}^{-1}\right): 1787(\mathrm{C}=\mathrm{O}), 1653(\mathrm{C}=\mathrm{N}), 1605$ (C=C). ${ }^{1} \mathrm{H}$ NMR $\left(400 \mathrm{MHz}, \mathrm{CDCl}_{3}\right): \delta_{\mathrm{H}} 8.33(4 \mathrm{H}, \mathrm{s}, 4 \mathrm{CH}$ aromatic), $8.23(4 \mathrm{H}, \mathrm{d}, J 7.2 \mathrm{~Hz}, 4 \mathrm{CH}$ aromatic), $7.65(2 \mathrm{H}, \mathrm{t}, J 7.4 \mathrm{~Hz}$, $2 \mathrm{CH}$ aromatic), $7.57\left(4 \mathrm{H}, \mathrm{t}, \mathrm{J} 7.3 \mathrm{~Hz}, 4 \mathrm{CH}\right.$ aromatic), $7.25(2 \mathrm{H}, \mathrm{s},=\mathrm{C} \underline{\mathrm{H}}) .{ }^{13} \mathrm{C} \mathrm{NMR}\left(100 \mathrm{MHz}, \mathrm{CDCl}_{3}\right): \delta_{\mathrm{C}} 167.4(\mathrm{CO})$, 162.2, 133.7, 132.6, 130.1, 129.1, 128.6, 135.8, 134.6, 125.4 (C aromatic). MS (ESI) $\mathrm{m} / z$ (\%): 420.11 (M+, 12.4\%), 67 (100). Anal. calc. for $\mathrm{C}_{26} \mathrm{H}_{16} \mathrm{~N}_{2} \mathrm{O}_{4}$ : C, 74.28; $\mathrm{H}, 3.84 ; \mathrm{N}, 6.66$. Found: C, 74.22; $\mathrm{H}, 3.90 ; \mathrm{N}, 6.59$.

(4Z,4'Z)-4,4'-[(1-Acetyl-1H-pyrazole-3,5-diyl)bis(methanylylidene)]bis(2-phenyloxazol-5(4H)-one] (2e).

Yellow solid, (402 mg, 89\%). mp 394-397 ${ }^{\circ} \mathrm{C}$. IR (solid, $\mathrm{KBr}, v_{\max } \mathrm{cm}^{-1}$ ): 1787, 1729 (C=O), 1648 (C=N), 1593 (C=C). ${ }^{1} \mathrm{H}$ NMR (400 MHz, DMSO): $\delta_{\mathrm{H}} 7.89-7.86(4 \mathrm{H}, \mathrm{m}, 4 \mathrm{CH}$ aromatic), $7.68(2 \mathrm{H}, \mathrm{s},=\mathrm{CH}), 7.57-7.50(6 \mathrm{H}, \mathrm{m}$, $6 \mathrm{CH}$ aromatic), $7.20\left(1 \mathrm{H}, \mathrm{s}\right.$, pyrazole-C4), $2.78\left(3 \mathrm{H}, \mathrm{s}, \mathrm{CH}_{3}\right)$. MS (ESI) $\mathrm{m} / z$ (\%): 452.11 (M+, $\left.0.3 \%\right), 105(100)$. Anal. calc. for $\mathrm{C}_{25} \mathrm{H}_{16} \mathrm{~N}_{4} \mathrm{O}_{5}$ : C, 66.37; $\mathrm{H}, 3.56 ; \mathrm{N}, 12.38$. Found: $\mathrm{C}, 66.42 ; \mathrm{H}, 3.49 ; \mathrm{N}, 12.44$. 
Methylene bis-\{2-[(Z)-(5-oxo-2-phenyloxazol-4(5H)-ylidene)methyl]-4,1-phenylene\} diacetate (2f).

Yellow solid, (588 mg, 94\%). $\mathrm{mp}>400^{\circ} \mathrm{C}$. IR (solid, $\mathrm{KBr}, v_{\max } \mathrm{cm}^{-1}$ ): 1803, 1736 (C=O), 1654 (C=N), 1597 (C=C). ${ }^{1} \mathrm{H}$ NMR (400 MHz, DMSO): $\delta_{\mathrm{H}} 7.93-7.90(4 \mathrm{H}, \mathrm{m}, 4 \mathrm{CH}$ aromatic), $7.66(2 \mathrm{H}, \mathrm{s},=\mathrm{C} \underline{\mathrm{H}}), 7.59-7.52(6 \mathrm{H}, \mathrm{m}, 6 \mathrm{CH}$ aromatic), $7.39(2 \mathrm{H}, \mathrm{d}, J 7.4 \mathrm{~Hz}, 2 \mathrm{CH}$ aromatic), $7.32(2 \mathrm{H}, \mathrm{s}, 2 \mathrm{CH}$ aromatic), $7.01(2 \mathrm{H}, \mathrm{d}, J 7.4 \mathrm{~Hz}, 2 \mathrm{CH}$ aromatic), $4.03\left(2 \mathrm{H}, \mathrm{s}, \mathrm{CH}_{2}\right), 2.42\left(6 \mathrm{H}, \mathrm{s}, \mathrm{CH}_{3}\right)$. MS (ESI) $\mathrm{m} / z$ (\%): $626.16\left(\mathrm{M}^{+}, 0.1 \%\right), 105$ (100). Anal. calc. for $\mathrm{C}_{37} \mathrm{H}_{26} \mathrm{~N}_{2} \mathrm{O}_{8}: \mathrm{C}_{\text {, }}$ 70.92; H, 4.18; N, 4.47. Found: C, 71.01; H, 4.11; N, 4.39.

(Z)-4-Benzylidene-2-phenyloxazol-5(4H)-one (9a)..$^{38}$ Yellow solid, (291 mg, 99\%). mp $167{ }^{\circ} \mathrm{C}$ (lit. mp 166-167). IR (solid, $\mathrm{KBr}, v_{\max } \mathrm{cm}^{-1}$ ): $1796(\mathrm{C}=\mathrm{O}), 1656(\mathrm{C}=\mathrm{N}), 1595(\mathrm{C}=\mathrm{C}) .{ }^{1} \mathrm{H}$ NMR (400 MHz, DMSO): $\delta_{\mathrm{H}} 8.31(2 \mathrm{H}, \mathrm{d}, J$ $7.8 \mathrm{~Hz}, 2 \mathrm{CH}$ aromatic), $8.13(2 \mathrm{H}, \mathrm{d}, J 7.5 \mathrm{~Hz}, 2 \mathrm{CH}$ aromatic), 7.61 (1H, t, J 7.4, 1CH aromatic), 7.53 (2H, t, J 7.7, $2 \mathrm{CH}$ aromatic), 7.51-7.42 (3H, m, 3CH aromatic), 7.32 (1H, s, CH=C). MS (ESI) m/z (\%): 294.08 (M+, $69 \%), 105$ (100). Anal. calc. for $\mathrm{C}_{16} \mathrm{H}_{11} \mathrm{NO}_{2}$ : C, 77.10; $\mathrm{H}, 4.45 ; \mathrm{N}, 5.62$. Found: $\mathrm{C}, 77.17 ; \mathrm{H}, 4.40 ; \mathrm{N}, 5.57$.

(Z)-4-(4-Chlorobenzylidene)-2-phenyloxazol-5(4H)-one (9b). ${ }^{39}$ Yellow solid, (277mg, 98\%). mp $204-206{ }^{\circ} \mathrm{C}$ (lit. mp 203-204). IR (solid, $\mathrm{KBr}, v_{\max } \mathrm{cm}^{-1}$ ): $1790(\mathrm{C}=\mathrm{O}), 1662(\mathrm{C}=\mathrm{N}), 1599(\mathrm{C}=\mathrm{C}) .{ }^{1} \mathrm{H}$ NMR (400 MHz, DMSO): $\delta_{H}$ : $8.20(1 \mathrm{H}, \mathrm{m}, 1 \mathrm{CH}$ aromatic), $8.17(1 \mathrm{H}, \mathrm{d}, J 1.5 \mathrm{~Hz}, 1 \mathrm{CH}$ aromatic), $8.15(1 \mathrm{H}, \mathrm{d}, J 1.7 \mathrm{~Hz}, 1 \mathrm{CH}$ aromatic), $8.141 \mathrm{H}$, $(1 \mathrm{H}, \mathrm{m}, 1 \mathrm{CH}$ aromatic), $7.64(1 \mathrm{H}, \mathrm{m}, 1 \mathrm{CH}$ aromatic), $7.54(2 \mathrm{H}, \mathrm{t}, J 7.7 \mathrm{~Hz}, 2 \mathrm{CH}$ aromatic $), 7.46(2 \mathrm{H}, \mathrm{m}, 2 \mathrm{CH}$ aromatic), $7.18(1 \mathrm{H}, \mathrm{s}, \mathrm{CH}=\mathrm{C})$. MS (ESI) $\mathrm{m} / z$ (\%): $283.04\left(\mathrm{M}^{+}, 34 \%\right), 103$ (100). Anal. calc. for $\mathrm{C}_{16} \mathrm{H}_{10} \mathrm{CINO}_{2}: \mathrm{C}$, 67.74; H, 3.55; N, 4.94. Found: C, 67.71; H, 3.59; N, 4.89.

(Z)-4-(4-Methylbenzylidene)-2-phenyloxazol-5(4H)-one (9c). ${ }^{39}$ Yellow solid, (260 mg, 99\%). mp $143-145{ }^{\circ} \mathrm{C}$ (lit. mp 144-145). IR (solid, KBr, $v_{\max }, \mathrm{cm}^{-1}$ ): 1788 (C=O), 1641 (C=N), 1603 (C=C). ${ }^{1} \mathrm{H}$ NMR (400 MHz, DMSO): $\delta_{H}$ $8.19(2 \mathrm{H}, \mathrm{dd}, J 1.3,8.2 \mathrm{~Hz}, 2 \mathrm{CH}$ aromatic), $8.10(2 \mathrm{H}, \mathrm{d}, J 8.2 \mathrm{~Hz}, 2 \mathrm{CH}$ aromatic), $7.58(1 \mathrm{H}, \mathrm{dd}, J 4.4,10.7 \mathrm{~Hz}, 1 \mathrm{CH}$ aromatic), $7.52(2 \mathrm{H}, \mathrm{dd}, J 7.1,8.2 \mathrm{~Hz}, 2 \mathrm{CH}$ aromatic), $7.30(2 \mathrm{H}, \mathrm{d}, J 8.3 \mathrm{~Hz}, 2 \mathrm{CH}$ aromatic), $7.24(1 \mathrm{H}, \mathrm{s}, \mathrm{CH}=\mathrm{C})$, $2.41\left(3 \mathrm{H}, \mathrm{s}, \mathrm{CH}_{3}\right)$. MS (ESI) $\mathrm{m} / z$ (\%): $263.09\left(\mathrm{M}^{+}, 11 \%\right), 91$ (100). Anal. calc. for $\mathrm{C}_{17} \mathrm{H}_{13} \mathrm{NO}_{2}: \mathrm{C}, 77.55 ; \mathrm{H}, 4.98 ; \mathrm{N}$, 5.32. Found: $C, 77.59 ; H, 4.96 ; N, 5.28$.

(Z)-4-[1-(1-Acetyl-1H-indol-3-yl)ethylidene]-2-phenyloxazol-5(4H)-one (9d). Yellow solid, (333 mg, 97\%). mp 312-315 ${ }^{\circ} \mathrm{C}$. IR (solid, $\mathrm{KBr}, v_{\max } \mathrm{Cm}^{-1}$ ): 1795, 1712 (C=O), 1655 (C=N), 1605 (C=C). ${ }^{1} \mathrm{H}$ NMR (400 MHz, DMSO): $\delta_{H}$ $8.34(1 \mathrm{H}, \mathrm{s}, 1 \mathrm{CH}$ aromatic), $8.23(1 \mathrm{H}, \mathrm{d}, J 7.6 \mathrm{~Hz}, 1 \mathrm{CH}$ aromatic), 8.20-8.17 (2H, m, 2CH aromatic), 7.55-7.51 (4H, m, 4CH aromatic), 7.24-7.21 (2H, m, 2CH aromatic), $2.49\left(3 \mathrm{H}, \mathrm{s}, \mathrm{CH}_{3}\right), 2.43\left(3 \mathrm{H}, \mathrm{s}, \mathrm{CH}_{3}\right) ;{ }^{13} \mathrm{C} \mathrm{NMR}(100$ $\mathrm{MHz}_{\mathrm{CDCl}}$ ): $\delta_{\mathrm{c}} 169.7$ (CO), 167.3 (CO), 161.4, 149.4, 137.5, 136.6, 134.3, 131.4, 129.0, 128.5, 126.4, 125.3, 122.7, 121.9, 121.3, 117.8, 110.3 (C aromatic), $24.5\left(\underline{\mathrm{CH}}_{3}\right), 20.7\left(\mathrm{CH}_{3}\right) . \mathrm{MS}(\mathrm{ESI}) \mathrm{m} / \mathrm{z}(\%): 344.11\left(\mathrm{M}^{+}, 0.8 \%\right), 105$ (100). Anal. calc. for $\mathrm{C}_{21} \mathrm{H}_{16} \mathrm{~N}_{2} \mathrm{O}_{3}: \mathrm{C}, 73.24 ; \mathrm{H}, 4.68 ; \mathrm{N}, 8.13$. Found: $\mathrm{C}, 73.30 ; \mathrm{H}, 4.61 ; \mathrm{N}, 8.06$.

(Z)-2-Phenyl-4-[1-(pyridin-4-yl)ethylidene]oxazol-5(4H)-one (9e). Yellow solid, (258 mg, 98\%). $\mathrm{mp} 215-217^{\circ} \mathrm{C}$. IR (solid, KBr, $v_{\max } \mathrm{cm}^{-1}$ ): 1788 (C=O), 1650 (C=N), 1611 (C=C). ${ }^{1} \mathrm{H}$ NMR (400 MHz, DMSO): $\delta_{H} 8.82-8.80(2 \mathrm{H}, \mathrm{m}$, $2 \mathrm{CH}$ aromatic), 8.02-7.99 (2H, m, 2CH aromatic), 7.73-7.71 (2H, m, 2CH aromatic), 7.53-7.50 (3H, m, 3CH aromatic), $2.54\left(3 \mathrm{H}, \mathrm{s}, \mathrm{CH}_{3}\right) ;{ }^{13} \mathrm{C} \mathrm{NMR}(100 \mathrm{MHz}, \mathrm{DMSO}): \delta_{\mathrm{C}} 167.5$ (CO), 161.9, 150.9, 149.2, 142.7, 138.5, 131.1, 128.8, 128.3, 125.9, 121.2 (C aromatic), $21.0\left(\underline{C}_{3}\right)$. MS (ESI) $m / z(\%): 264.08$ (M+, $\left.0.8 \%\right), 105$ (100). Anal. calc. for $\mathrm{C}_{16} \mathrm{H}_{12} \mathrm{~N}_{2} \mathrm{O}_{2}$ : C, 72.72; $\mathrm{H}, 4.58 ; \mathrm{N}, 10.60$. Found: $\mathrm{C}, 72.68 ; \mathrm{H}, 4.66 ; \mathrm{N}, 10.54$.

(Z)-2-Phenyl-4-[1-(pyridin-2-yl)ethylidene]oxazol-5(4H)-one (9f). Yellow solid, (237 mg, 90\%). $\mathrm{mp} 228-231{ }^{\circ} \mathrm{C}$. IR (solid, KBr, $v_{\max } \mathrm{cm}^{-1}$ ): 1785 (C=O), $1643(\mathrm{C}=\mathrm{N}), 1605$ (C=C). ${ }^{1 \mathrm{H}} \mathrm{NMR}(400 \mathrm{MHz}, \mathrm{DMSO}): \delta_{\mathrm{H}} 8.69-8.68(1 \mathrm{H}, \mathrm{m}$, $1 \mathrm{CH}$ aromatic), 8.04-8.01 (3H, m, 3CH aromatic), 7.84-7.83 (1H, m, 1CH aromatic), 7.54-7.52 (3H, $\mathrm{m}, 3 \mathrm{CH}$ aromatic), 7.48-7.47 (1H, m, 1CH aromatic), $2.52\left(3 \mathrm{H}, \mathrm{s}, \mathrm{C}_{3}\right) .{ }^{13} \mathrm{C} \mathrm{NMR}(100 \mathrm{MHz}, \mathrm{DMSO}): \delta_{\mathrm{c}} 167.3(\mathrm{CO})$, 161.7, 153.6, 149.7, 148.8, 138.9, 136.4, 131.0, 128.6, 128.1, 127.3, 126.1, 121.5 (C aromatic), $24.2\left(\underline{C} \mathrm{H}_{3}\right) . \mathrm{MS}$ (ESI) $\mathrm{m} / \mathrm{z}$ (\%): $264.08\left(\mathrm{M}^{+}, 2.5\right), 105$ (100). Anal. calc. for $\mathrm{C}_{16} \mathrm{H}_{12} \mathrm{~N}_{2} \mathrm{O}_{2}: \mathrm{C}, 72.72 ; \mathrm{H}, 4.58 ; \mathrm{N}, 10.60$. Found: C, 72.70; H, 4.62; N, 10.57 . 


\section{Synthesis of derivatives (3) and (4)}

A mixture of 2-hydroxy-5-methylisophthalaldehyde $(0.5 \mathrm{mmol}), \mathrm{HA}(1 \mathrm{mmol}), \mathrm{Ac}_{2} \mathrm{O}(2 \mathrm{~mL})$ and $\mathrm{NaOAc}(2.1$ mmol) was warmed into solution. Heating was then continued on an oil-bath for $1 \mathrm{~h}$. Excess acetic anhydride was decomposed with water, and the residue was triturated with ethanol. The yellow solid product was filtered off and the crude product was subjected to preparative TLC (DCM:MeOH 8:2) to afford derivatives (2a) $\left(R_{f} 0.4\right),(3)\left(R_{f} 0.42\right)$ and $(4)\left(R_{f} 0.45\right)$.

(Z)-4-((6-Methyl-2-oxo-2H-chromen-8-yl)methylene)-2-phenyloxazol-5(4H)-one (3). Yellow solid, (198 mg, 60\%). mp 201-203 ${ }^{\circ} \mathrm{C}$. IR (solid, $\mathrm{KBr}, v_{\max } \mathrm{cm}^{-1}$ ): 1788, $1736(\mathrm{C}=\mathrm{O}), 1636(\mathrm{C}=\mathrm{N}), 1612$ (C=C). ${ }^{1} \mathrm{H} \mathrm{NMR}(400 \mathrm{MHz}$, DMSO): $\delta_{\mathrm{H}} 7.99-7.98(2 \mathrm{H}, \mathrm{m}, 2 \mathrm{CH}$ aromatic), $7.92(1 \mathrm{H}, \mathrm{d}, J 9.6 \mathrm{~Hz}, 1 \mathrm{CH}$ aromatic), $7.80(1 \mathrm{H}, \mathrm{s}, \mathrm{C} \underline{\mathrm{H}}=\mathrm{C}), 7.46-7.44$ (3H, m, 3CH aromatic), 7.26-7.25 (2H, m, 2CH aromatic), $6.42\left(1 \mathrm{H}, \mathrm{d}, J 9.6 \mathrm{~Hz}, 1 \mathrm{CH}\right.$ aromatic), 2.40 (3H, s, $\left.\underline{\mathrm{C}}_{3}\right)$. MS (ESI) $m / z$ (\%): 331.07 ( $\left.\mathrm{M}^{+}, 1.5 \%\right), 103$ (100). Anal. calc. for $\mathrm{C}_{20} \mathrm{H}_{13} \mathrm{NO}_{4}: \mathrm{C}, 72.50 ; \mathrm{H}, 3.96 ; \mathrm{N}, 4.23$. Found: $\mathrm{C}$, 72.53; H, 3.99; N, 4.19.

3,3'-(2-Acetoxy-5-methyl-1,3-phenylene)diacrylic acid (4). Yellow solid, (17 mg, 6\%). mp 187-189 ${ }^{\circ} \mathrm{C}$. IR (solid, $\mathrm{KBr}, v_{\max } \mathrm{Cm}^{-1}$ ): 3411-2877 (OH), 1715, $1689(\mathrm{C}=\mathrm{O}), 1605(\mathrm{C}=\mathrm{C}) .{ }^{1} \mathrm{H}$ NMR (400 MHz, DMSO): $\delta_{\mathrm{H}} 12.76(2 \mathrm{H}, \mathrm{br}$, $\mathrm{OH}), 8.12(2 \mathrm{H}, \mathrm{d}, J 14.9 \mathrm{~Hz}, \mathrm{C} \underline{\mathrm{H}}=\mathrm{CH}-\mathrm{CO}), 7.32(2 \mathrm{H}, \mathrm{s}, 2 \mathrm{CH}$ aromatic), $6.25(2 \mathrm{H}, \mathrm{d}, J 9.4 \mathrm{~Hz}, \mathrm{CH}=\mathrm{C} \underline{\mathrm{H}}-\mathrm{CO}), 2.39(3 \mathrm{H}$, s, $\left.\underline{\mathrm{C}}_{3}\right), 2.36\left(3 \mathrm{H}, \mathrm{s}, \underline{\mathrm{C}}_{3}\right) .{ }^{13} \mathrm{C} \mathrm{NMR}(100 \mathrm{MHz}, \mathrm{DMSO}): \delta_{\mathrm{c}} 171.2$ (CO), 169.5 (CO), 143.2, 142.7, 133.0, 128.4, 124.3, 117.0 (C aromatic), $21.1\left(\underline{\mathrm{CH}}_{3}\right), 20.4\left(\underline{\mathrm{CH}}_{3}\right) . \mathrm{MS}(\mathrm{ESI}) \mathrm{m} / \mathrm{z}(\%): 290.05\left(\mathrm{M}^{+}, 0.1 \%\right), 202$ (100). Anal. calc. for $\mathrm{C}_{15} \mathrm{H}_{14} \mathrm{O}_{6}$ : $\mathrm{C}, 62.07 ; \mathrm{H}, 4.86$. Found: $\mathrm{C}, 62.11 ; \mathrm{H}, 4.82$.

\section{General protocol for the synthesis of bis-imidazoles (11a-i)}

A mixture of (Z)-4-arylidene-2-phenyloxazol-5(4H)-ones (9a-c, $1 \mathrm{mmol})$ and diamines (10a-c, $0.5 \mathrm{mmol})$ in ethanol $(10 \mathrm{~mL})$ containing a catalytic quantity of $\mathrm{NaOAC}$ was sonicated for $10 \mathrm{~min}$ at $80{ }^{\circ} \mathrm{C}$ (monitored by TLC). The formed crude products were filtered, dried and recrystallized from dioxane containing a few drops of DMF.

(Z)-3,3'-((1R,4R)-Cyclohexane-1,4-diyl)bis-[5-((Z)-benzylidene)-2-phenyl-3,5-dihydro-4H-imidazol-4-one]

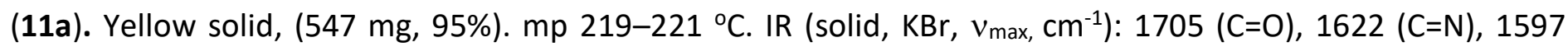
(C=C). ${ }^{1} \mathrm{H}$ NMR (400 MHz, DMSO): $\delta_{\mathrm{H}} 8.27-8.21(4 \mathrm{H}, \mathrm{m}, 4 \mathrm{CH}$ aromatic), 7.56-7.47 (6H, $\mathrm{m}, 6 \mathrm{CH}$ aromatic), 7.43$7.29(10 \mathrm{H}, \mathrm{m}, 10 \mathrm{CH}$ aromatic), $7.11(2 \mathrm{H}, \mathrm{s}, \mathrm{CH}=\mathrm{C}), 4.22(2 \mathrm{H}, \mathrm{b}, \mathrm{cyclohexyl}), 1.77-1.75$ (4H, m, cyclohexyl), 1.44$1.40\left(4 \mathrm{H}, \mathrm{m}\right.$, cyclohexyl). ${ }^{13} \mathrm{C}$ NMR (100 MHz, DMSO): $\delta_{c} 170.9$ (CO), 152.7, 138.7, 132.0, 130.5, 128.9, 128.8, 127.2, 126.7, 117.7, 116.9 (C aromatic), 57.8 (C aliphatic), 30.8 (C aliphatic). MS (ESI) m/z (\%): 576.25 (M $0.5 \%), 90$ (100). Anal. calc. for $\mathrm{C}_{38} \mathrm{H}_{32} \mathrm{~N}_{4} \mathrm{O}_{2}: \mathrm{C}, 79.14 ; \mathrm{H}, 5.59 ; \mathrm{N}, 9.72$. Found: $\mathrm{C}, 79.19 ; \mathrm{H}, 5.51 ; \mathrm{N}, 9.65$.

(Z)-3,3'-((1R,4R)-Cyclohexane-1,4-diyl)bis[5-((Z)-4-chlorobenzylidene)-2-phenyl-3,5-dihydro-4H-imidazol-4one] (11b). Yellow solid, (624 mg, 97\%). mp 312-315 ${ }^{\circ} \mathrm{C}$. IR (solid, $\mathrm{KBr}, v_{\max } \mathrm{cm}^{-1}$ ): 1701 (C=O), 1641 (C=N), $1604(\mathrm{C}=\mathrm{C}) .{ }^{1} \mathrm{H}$ NMR (400 MHz, DMSO): $\delta_{\mathrm{H}} 8.21-8.12(8 \mathrm{H}, \mathrm{m}, 8 \mathrm{CH}$ aromatic), $7.66(2 \mathrm{H}, \mathrm{m}, 2 \mathrm{CH}$ aromatic), 7.57 $(4 \mathrm{H}, \mathrm{m}, 4 \mathrm{CH}$ aromatic), $7.43(4 \mathrm{H}, \mathrm{m}, 4 \mathrm{CH}$ aromatic), $7.21(2 \mathrm{H}, \mathrm{s}, \mathrm{CH}=\mathrm{C}), 4.20(2 \mathrm{H}, \mathrm{b}, \mathrm{cyclohexyl}), 1.76-1.73(4 \mathrm{H}$, m, cyclohexyl), 1.44-1.42 (4H, m, cyclohexyl). MS (ESI) m/z (\%): 644.17 ( $\left.\mathrm{M}^{+}, 0.9 \%\right), 103$ (100). Anal. calc. for $\mathrm{C}_{38} \mathrm{H}_{30} \mathrm{Cl}_{2} \mathrm{~N}_{4} \mathrm{O}_{2}$ : C, 70.70; $\mathrm{H}, 4.68 ; \mathrm{N}, 8.68$. Found: $\mathrm{C}, 70.75 ; \mathrm{H}, 4.61 ; \mathrm{N}, 8.60$.

(Z)-3,3'-((1R,4R)-Cyclohexane-1,4-diyl)bis[5-((Z)-4-methylbenzylidene)-2-phenyl-3,5-dihydro-4H-imidazol-4one] (11c). Yellow solid, (570 mg, 96\%). mp 279-282 ${ }^{\circ} \mathrm{C}$. IR (solid, $\left.\mathrm{KBr}, v_{\max } \mathrm{cm}^{-1}\right)$ : 1697 (C=O), 1635 (C=N), $1586(\mathrm{C}=\mathrm{C}) .{ }^{1} \mathrm{H}$ NMR (400 MHz, DMSO): $\delta_{\mathrm{H}} 8.21-8.17(8 \mathrm{H}, \mathrm{m}, 8 \mathrm{CH}$ aromatic), 7.60-7.57 (6H, $\mathrm{m}, 6 \mathrm{CH}$ aromatic), 7.33-7.29 (4H, m, 4CH aromatic), $7.27(2 \mathrm{H}, \mathrm{s}, \underline{\mathrm{C}} \underline{\mathrm{H}}=\mathrm{C}), 4.24(2 \mathrm{H}, \mathrm{b}, \mathrm{cyclohexyl}), 2.42\left(6 \mathrm{H}, \mathrm{s}, \mathrm{C}_{3}\right), 1.78-1.72(4 \mathrm{H}$, m, cyclohexyl), 1.46-1.42 (4H, m, cyclohexyl). MS (ESI) $m / z(\%): 604.28\left(\mathrm{M}^{+}, 1.6 \%\right), 103$ (100). Anal. calc. for $\mathrm{C}_{40} \mathrm{H}_{36} \mathrm{~N}_{4} \mathrm{O}_{2}:$ C, 79.44; $\mathrm{H}, 6.00 ; \mathrm{N}, 9.26$. Found: $\mathrm{C}, 79.49 ; \mathrm{H}, 5.97 ; \mathrm{N}, 9.21$.

(Z)-3,3'-[1,4-Phenylenebis(methylene)]bis[5-((Z)-benzylidene)-2-phenyl-3,5-dihydro-4H-imidazol-4-one] (11d). Yellow solid, (550 mg, 92\%). mp 284-286 ${ }^{\circ} \mathrm{C}$. IR (solid, KBr, v $\max , \mathrm{cm}^{-1}$ ): 1712 (C=O), 1641 (C=N), 1601 
(C=C). ${ }^{1} \mathrm{H}$ NMR (400 MHz, DMSO): $\delta_{\mathrm{H}} 8.25-8.23(4 \mathrm{H}, \mathrm{m}, 4 \mathrm{CH}$ aromatic), 7.55-7.48 (6H, m, 6CH aromatic), 7.48$7.25\left(10 \mathrm{H}, \mathrm{m}, 10 \mathrm{CH}\right.$ aromatic), $7.23\left(4 \mathrm{H}, \mathrm{s}, 4 \mathrm{CH}\right.$ aromatic), $7.06(2 \mathrm{H}, \mathrm{s}, \mathrm{C} \underline{\mathrm{H}}=\mathrm{C}), 4.69\left(4 \mathrm{H}, \mathrm{s}, \mathrm{CH}_{2}\right) .{ }^{13} \mathrm{C} \mathrm{NMR}(100$ $\mathrm{MHz}, \mathrm{DMSO}$ ): $\delta_{\mathrm{c}} 170.9$ (CO), 152.8, 138.9, 136.5, 132.1, 131.2, 129.0, 128.8, 128.1, 127.2, 117.5 (C aromatic), 53.0 (C aliphatic). MS (ESI) $\mathrm{m} / z$ (\%): $598.23\left(\mathrm{M}^{+}, 0.33 \%\right), 90$ (100). Anal. calc. for $\mathrm{C}_{40} \mathrm{H}_{30} \mathrm{~N}_{4} \mathrm{O}_{2}: \mathrm{C}, 80.25 ; \mathrm{H}, 5.05$; N, 9.36. Found: C, 80.21; H, 5.10; N, 9.29.

(Z)-3,3'-[1,4-Phenylenebis(methylene)]bis[5-((Z)-4-chlorobenzylidene)-2-phenyl-3,5-dihydro-4H-imidazol-4one] (11e). Yellow solid, (626 mg, 94\%), mp 379-382 ${ }^{\circ} \mathrm{C} . \mathrm{IR}$ (solid, $\mathrm{KBr}, v_{\max } \mathrm{cm}^{-1}$ ): 1701 (C=O), 1639 (C=N), $1612(\mathrm{C}=\mathrm{C}) .{ }^{1} \mathrm{H} N M R(400 \mathrm{MHz}, \mathrm{DMSO}): \delta_{\mathrm{H}} 8.23-8.17(8 \mathrm{H}, \mathrm{m}, 8 \mathrm{CH}$ aromatic), 7.67-7.61 (6H, $\mathrm{m}, 6 \mathrm{CH}$ aromatic), 7.46-7.43 (4H, m, 4CH aromatic), $7.23(2 \mathrm{H}, \mathrm{s}, \mathrm{C} \underline{\mathrm{H}}=\mathrm{C}), 7.22\left(4 \mathrm{H}, \mathrm{s}, 4 \mathrm{CH}\right.$ aromatic), $4.65\left(4 \mathrm{H}, \mathrm{s}, \mathrm{C}_{2}\right) . \mathrm{MS}$ (ESI) $\mathrm{m} / z$ (\%): $666.16\left(\mathrm{M}^{+}, 1.61 \%\right), 103$ (100). Anal. calc. for $\mathrm{C}_{40} \mathrm{H}_{28} \mathrm{Cl}_{2} \mathrm{~N}_{4} \mathrm{O}_{2}$ : C, 71.97; $\mathrm{H}, 4.23 ; \mathrm{N}, 8.39$. Found: $\mathrm{C}, 72.01 ; \mathrm{H}$, $4.21 ; \mathrm{N}, 8.35$.

(Z)-3,3'-[1,4-Phenylenebis(methylene)]bis[5-((Z)-4-methylbenzylidene)-2-phenyl-3,5-dihydro-4H-imidazol-4-

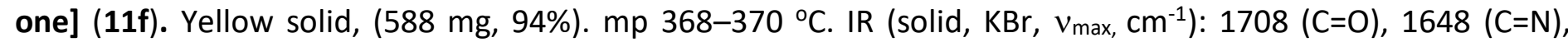
$1597(\mathrm{C}=\mathrm{C}) .{ }^{1} \mathrm{H}$ NMR $(400 \mathrm{MHz}, \mathrm{DMSO}): \delta_{\mathrm{H}} 8.24-8.19(8 \mathrm{H}, \mathrm{m}, 8 \mathrm{CH}$ aromatic), 7.55-7.53 (2H, m, 2CH aromatic), 7.48-7.39 (8H, m, 8CH aromatic), $7.24\left(4 \mathrm{H}, \mathrm{s}, 4 \mathrm{CH}\right.$ aromatic), $7.14(1 \mathrm{H}, \mathrm{s}, \mathrm{C} \underline{\mathrm{H}}=\mathrm{C}), 4.66\left(4 \mathrm{H}, \mathrm{s}, \underline{\mathrm{C}}_{2}\right), 2.42(3 \mathrm{H}, \mathrm{s}$, $\left.\mathrm{CH}_{3}\right)$. MS (ESI) $m / z(\%): 626.27\left(\mathrm{M}^{+}, 10.6 \%\right), 91(100)$. Anal. calc. for $\mathrm{C}_{42} \mathrm{H}_{34} \mathrm{~N}_{4} \mathrm{O}_{2}: \mathrm{C}, 80.49 ; \mathrm{H}, 5.47 ; \mathrm{N}, 8.94$. Found: C, 80.53; $\mathrm{H}, 5.44 ; \mathrm{N}, 8.89$.

(Z)-3,3'-(Ethane-1,2-diyl)bis[5-((Z)-benzylidene)-2-phenyl-3,5-dihydro-4H-imidazol-4-one $] \quad(11 \mathrm{~g}) .{ }^{37} \quad$ Yellow solid, (490 mg, 94\%). mp 145-147 ${ }^{\circ} \mathrm{C}$ (lit mp 140-142 ${ }^{\circ} \mathrm{C}$ ). IR (solid, KBr, $\left.v_{\max } \mathrm{cm}^{-1}\right)$ : $1701(\mathrm{C}=\mathrm{O}), 1637(\mathrm{C}=\mathrm{N})$, $1612(\mathrm{C}=\mathrm{C}) .{ }^{1} \mathrm{H}$ NMR (400 MHz, DMSO): $\delta_{\mathrm{H}} 8.28-8.23(4 \mathrm{H}, \mathrm{m}, 4 \mathrm{CH}$ aromatic), 7.56-7.43 (6H, m, 6CH aromatic) 7.44-7.27 (10H, m, 10CH aromatic), $7.12(2 \mathrm{H}, \mathrm{s}, \mathrm{C} \underline{\mathrm{H}}=\mathrm{C}), 4.36\left(4 \mathrm{H}, \mathrm{s}, \mathrm{C}_{2}\right) .{ }^{13} \mathrm{C} \mathrm{NMR}(100 \mathrm{MHz}, \mathrm{DMSO}): \delta \mathrm{c} 170.9$ (CO), 152.8, 139.0, 132.3, 130.7, 129.1, 128.8, 127.3, 127.0, 117.6 (C aromatic), 51.3 (C alphatic). MS (ESI) $\mathrm{m} / \mathrm{z}$ (\%): $522.20\left(\mathrm{M}^{+}, 2.5 \%\right), 103$ (100). Anal. calc. for $\mathrm{C}_{34} \mathrm{H}_{26} \mathrm{~N}_{4} \mathrm{O}_{2}$ : C, 78.14; $\mathrm{H}, 5.01 ; \mathrm{N}, 10.72$. Found: $\mathrm{C}, 78.19 ; \mathrm{H}$, 4.96; N, 10.68.

(Z)-3,3'-(Ethane-1,2-diyl)bis-[5-((Z)-4-chlorobenzylidene)-2-phenyl-3,5-dihydro-4H-imidazol-4-one] (11h). Yellow solid, (560 mg, 95\%). mp 312-314 ${ }^{\circ} \mathrm{C}$. IR (solid, $\left.\mathrm{KBr}, v_{\max }, \mathrm{cm}^{-1}\right): 1713$ (C=O), $1641(\mathrm{C}=\mathrm{N}), 1609$ (C=C). ${ }^{1} \mathrm{H}$ NMR (400 MHz, DMSO): $\delta_{\mathrm{H}} 8.21-8.15(8 \mathrm{H}, \mathrm{m}, 8 \mathrm{CH}$ aromatic), 7.68-7.60 (6H, m, 6CH aromatic), 7.44-7.40 (4H, $\mathrm{m}, 4 \mathrm{CH}$ aromatic), 7.22-7.18 (2H, m, 2CH aromatic), 4.33 (4H, s, $\left.\underline{\mathrm{C}}_{2}\right) . \mathrm{MS}$ (ESI) $\mathrm{m} / \mathrm{z}(\%): 590.12\left(\mathrm{M}^{+}, 2.5 \%\right), 103$ (100). Anal. calc. for $\mathrm{C}_{34} \mathrm{H}_{24} \mathrm{Cl}_{2} \mathrm{~N}_{4} \mathrm{O}_{2}: \mathrm{C}, 69.04 ; \mathrm{H}, 4.09 ; \mathrm{N}, 9.47$. Found: $\mathrm{C}, 69.09 ; \mathrm{H}, 4.05 ; \mathrm{N}, 9.42$.

(Z)-3,3'-(Ethane-1,2-diyl)bis(5-[(Z)-4-methylbenzylidene)-2-phenyl-3,5-dihydro-4H-imidazol-4-one]

(11i).

Yellow solid, (533 mg, 97\%). mp 199-202 ${ }^{\circ} \mathrm{C}$. IR (solid, KBr, $\left.v_{\max }, \mathrm{cm}^{-1}\right): 1698(\mathrm{C}=\mathrm{O}), 1628(\mathrm{C}=\mathrm{N}), 1610$ (C=C). ${ }^{1} \mathrm{H}$ NMR (400 MHz, DMSO): $\delta_{\mathrm{H}} 8.15-8.08(8 \mathrm{H}, \mathrm{m}, 8 \mathrm{CH}$ aromatic), 8.17-8.15 (4H, m, 4CH aromatic), 7.59-7.66 (6H, $\mathrm{m}, 6 \mathrm{CH}$ aromatic), 7.35-7.29 (4H, m, $4 \mathrm{CH}$ aromatic), $7.21(2 \mathrm{H}, \mathrm{s}, \mathrm{C} \underline{\mathrm{H}}=\mathrm{C}), 4.37\left(4 \mathrm{H}, \mathrm{s}, \mathrm{C}_{2}\right), 2.40\left(6 \mathrm{H}, \mathrm{s}, \mathrm{C} \underline{H}_{3}\right) . \mathrm{MS}$ (ESI) $\mathrm{m} / \mathrm{z}$ (\%): $550.23\left(\mathrm{M}^{+}, 5.3 \%\right), 91$ (100). Anal. calc. for $\mathrm{C}_{36} \mathrm{H}_{30} \mathrm{~N}_{4} \mathrm{O}_{2}: \mathrm{C}, 78.52 ; \mathrm{H}, 5.49 ; \mathrm{N}, 10.17$. Found: $\mathrm{C}$, 78.56; H, 5.51; N, 10.11 .

\section{References}

1. Paul, S.; Nanda, P.; Gupta, R.; Loupy, A. Tetrahedron Lett. 2004, 45, 425-427. https://doi.org/10.1016/i.tetlet.2003.10.125.

2. Sierra, F. M. P.; Pierre, A.; Burbridge, M.; Guilbaud, N. Bioorg. Med. Chem. Lett. 2002, 12, 1463-1466. https://doi:org/10.1016/S0960-894X(02)00197-X. 
3. Takenaka, K.; Tsuji, T. J. Heterocyclic Chem. 1996, 33, 1367-1370. https://doi:org/10.1002/jhet.5570330459

4. Mohammed, K. K.; Mughal, M. R.; Hassan, K. M. T. Bioorg. Med. Chem. 2006, 14, 6027-6033. https://doi:org/10.1016/j.bmc.2006.05.014.

5. Weber, M.; Frey, W.; Peters, R. Adv. Synth. Catal. 2012, 354, 1443-1449. https://doi:10.1002/adsc.201200085.

6. Esguevillas, M. G.; Adrio, J.; Carretero, J. C. Chem. Commun. 2013, 49, 4649-4652. https://doi:10.1039/C3CC41663A

7. Tian, L.; Xu, G. Q.; Li, Y. H.; Liang, Y. M.; Xu, P. F. Chem. Commun. 2014, 50, 2428-2430. https://doi:10.1039/C3CC49504C

8. Wang, T.; Yu, Z.; Hoon, D. L.; Phee, C. Y.; Lan, Y.; Lu, Y. J. Am. Chem. Soc. 2015, 138, 265-271. https://doi:10.1021/jacs.5b10524

9. Cavalier, F.; Verducci, J. Tetrahedron Lett. 1995, 36, 4425-4428. https://doi.org/10.1016/0040-4039(95)00762-2

10. Avenoza, A.; Busto, J. H.; Cativiela, C.; Peregrina, J. M. Tetrahedron Lett. 2002, 43, 4167-4170. https://doi:org/10.1016/S0040-4039(02)00744-X

11. Erlenmeyer, E. Ann. 1892, 271, 137.

12. Hermanson, G.T.; Mattson, G. R.; Krohn, R. I. J. Chromatogr. A 1995, 691, 113-122.

13. Bautista, F. M.; Campelo, J. M.; Garcia, A.; Luna, D.; Marinas, J. M.; Romero, A. A. J. Chem. Soc., Perkin Trans. 2002, 2, 227-234. https://doi:10.1039/B109413K

14. Banafshe, S.; Ghaleh, T.; Valiollah, M.; Iraj, M. B.; Majid, M.; Shahram, T.; Mahbubeh, R.; Ahmad, R. K. J. Inorg. Organomet. Polym. 2013, 23, 758-765. https://doi:org/10.1007/s10904-012-9810-9

15. Conway, P. A.; Devine, K.; Paradisi, F. Tetrahedron. 2009, 65, 2935-2938. https://doi:org/10.1016/i.tet.2009.02.011

16. Yu, C.; Zhou, B.; Su, W.; Xu, Z. Synth. Commun. 2006, 36, 3447-3453. https://doi:org/10.1080/00397910600941521

17. Fisk, J. S.; Mosey, R. A.; Tepe, J. J. Chem. Soc. Rev. 2007, 36, 1432-1440. https://doi:10.1039/b511113g

18. Ramadan, M. A.; Hadeer, M. B.; Gammal, H. T.; Wael, A. A. A. J. Heterocyclic Chem. 2012, 49, 1071-1076. https://doi:10.1002/ihet.938

19. Roiban, G. D.; Soler, T.; Grosu, I.; Cativiela, C.; Urriolabeitia, E. P. Inorg. Chim. Acta 2011, 368, $247-251$. https://doi:org/10.1016/j.ica.2010.12.054

20. Esmail, V.; Somayeh, S. A.; Akram, H.; Ladan, E.; Ahmadreza, B. RSC Adv. 2017, 7, 7079-7091. https://doi:10.1039/C6RA25816F

21. Masoud, N. E.; Morteza, M.; Tooba, A. Chem. Pap. 2015, 69, 1491-1499. https://doi:org/10.1515/chempap-2015-0156

22. Rani, N.; Sharma, A.; Singh, R. Mini-Rev. Org. Chem. 2015, 12, 34-65. https://doi:10.2174/1570193X11666141028235010.

23. Mossaraf, H.; Kiran, P.; Ashis, K. N. Tetrahedron Lett. 2017, 58, 3772-3776. https://doi:org/10.1016/i.tetlet.2017.08.047 
24. Serykh, V. Y.; Kaliev, A. R.; Ushakov, I. A.; Borodina, T. N.; Smirnov, V.I.; Rozentsveig, I. B.; Arkivoc 2018, iii, 62-75.

https://doi.org/10.24820/ark.5550190.p010.357

25. Leila, Z. F.; Mohammad, N.; Roghayeh, M. J. Mol. Liq. 2016, 222, 77-81. https://doi:org/10.1016/i.molliq.2016.07.009

26. Hu, Y.; Shen, Y.; Wu, X.; Tu, X.; Wang, G. X. Eur. J. Med. Chem. 2018, 143, 958-969. https://doi:org/10.1016/j.ejmech.2017.11.100

27. Kokel, A.; Schafer, C.; Torok, B. Green Chem. 2017, 19, 3729-3751. https://doi:10.1039/C7GC01393K

28. Banerjee, B. Ultrason. Sonochem. 2017,35, 1-14. https://doi:org/10.1016/j.ultsonch.2016.09.023

29. Karoui, H.; Ritchie, C. New J. Chem. 2018, 42, 25-28. https://doi:10.1039/C7NJ02820B.

30. Arafa, W. A. A.; Abdel-Magied, A. F. Arkivoc, 2017, (v), 327-340. https://doi:org/10.24820/ark.5550190.p010.197

31. Arafa, W. A. A.; Mohamed, A. M.; Abdel-Magied, A. F. Heterocycles 2017, 94, 1439-1455. https://doi:10.3987/COM-17-13726

32. Arafa, W. A. A.; Fareed, M. F.; Rabeh, S. A.; Shaker, R. M. Phosphorus Sulfur Silicon Relat. Elem. 2016, 191, 1129-1136.

https://doi:org/10.1080/10426507.2016.1146276

33. Arafa, W. A. A.; Shaker, R. M.; Rabeh, S. A. Heterocycles 2016, 92, 1224-1243. https://doi:10.3987/COM-16-13479.

34. Arafa, W. A. A.; Kärkäs, M. D.; Lee, B. L.; Åkermark, T.; Liao, R. Z.; Berends, H. M.; Messinger, J.; Siegbahn, P. E. M.; Åkermark , B. Phys. Chem. Chem. Phys. 2014, 16, 11950-11964. https://doi.org/10.1039/c3cp54800g

35. Roiban, G. D.; Serrano, E.; Soler, T.; Contel, M.; Grosu, I.; Cativiela, C.; Urriolabeitia, E. P. Organometallics 2010, 29, 1428-1435. https://doi:10.1021/om901068f.

36. González, C. J.; Constable, D. J. C.; Ponder, C. S. Chem. Soc. Rev. 2012. 41, 1485-1498. https://doi:10.1039/C1CS15215G

37. Manoj, D. P. Asian J. Chem. 2001, 13, 226-230.

38. Canan, K.; Ezgi, U.; Elçin, D. Ö.; Benay, C. E. Turk. J. Pharm. Sci. 2017, 14, 174-178. https://doi:10.4274/tips.70299

39. Satya, P.; Puja, N.; Rajive, G.; Andre, L. Tetrahedron Lett. 2004, 45, 425-427. https://doi:org/10.1016/i.tetlet.2003.10.125. 